\title{
Primary and secondary sources of formaldehyde in urban atmospheres: Houston Texas region
}

\author{
D. D. Parrish ${ }^{1}$, T. B. Ryerson ${ }^{1}$, J. Mellqvist ${ }^{2}$, J. Johansson ${ }^{2}$, A. Fried ${ }^{3}$, D. Richter ${ }^{3}$, J. G. Walega ${ }^{3}$, \\ R. A. Washenfelder ${ }^{1,4}$, J. A. de Gouw ${ }^{1,4}$, J. Peischl ${ }^{1,4}$, K. C. Aikin ${ }^{1,4}$, S. A. McKeen ${ }^{1,4}$, G. J. Frost ${ }^{1,4}$, \\ F. C. Fehsenfeld ${ }^{1,4}$, and S. C. Herndon ${ }^{5}$ \\ ${ }^{1}$ NOAA ESRL Chemical Sciences Division, 325 Broadway, Boulder, CO, USA \\ ${ }^{2}$ Earth and Space Sciences, Chalmers University of Technology, Gothenburg, Sweden \\ ${ }^{3}$ Earth Observing Laboratory, National Center for Atmospheric Research, Boulder, CO, USA \\ ${ }^{4}$ CIRES, University of Colorado, Boulder, CO, USA \\ ${ }^{5}$ Aerodyne Research, Inc., Billerica, Massachusetts, USA
}

Correspondence to: D. D. Parrish (david.d.parrish@ noaa.gov)

Received: 25 October 2011 - Published in Atmos. Chem. Phys. Discuss.: 10 December 2011

Revised: 14 March 2012 - Accepted: 27 March 2012 - Published: 5 April 2012

\begin{abstract}
We evaluate the rates of secondary production and primary emission of formaldehyde $\left(\mathrm{CH}_{2} \mathrm{O}\right)$ from petrochemical industrial facilities and on-road vehicles in the Houston Texas region. This evaluation is based upon ambient measurements collected during field studies in 2000, 2006 and 2009. The predominant $\mathrm{CH}_{2} \mathrm{O}$ source $(92 \pm 4 \%$ of total) is secondary production formed during the atmospheric oxidation of highly reactive volatile organic compounds (HRVOCs) emitted from the petrochemical facilities. Smaller contributions are primary emissions from these facilities $(4 \pm 2 \%)$, and secondary production $(\sim 3 \%)$ and primary emissions $(\sim 1 \%)$ from vehicles. The primary emissions from both sectors are well quantified by current emission inventories. Since secondary production dominates, control efforts directed at primary $\mathrm{CH}_{2} \mathrm{O}$ emissions cannot address the large majority of $\mathrm{CH}_{2} \mathrm{O}$ sources in the Houston area, although there may still be a role for such efforts. Ongoing efforts to control alkene emissions from the petrochemical facilities, as well as volatile organic compound emissions from the motor vehicle fleet, will effectively reduce the $\mathrm{CH}_{2} \mathrm{O}$ concentrations in the Houston region. We do not address other emission sectors, such as off-road mobile sources or secondary formation from biogenic hydrocarbons. Previous analyses based on correlations between ambient concentrations of $\mathrm{CH}_{2} \mathrm{O}$ and various marker species have suggested much larger primary emissions of $\mathrm{CH}_{2} \mathrm{O}$, but those results neglect confounding effects of dilution and loss processes,
\end{abstract}

and do not demonstrate the causes of the observed correlations. Similar problems must be suspected in any source apportionment analysis of secondary species based upon correlations of ambient concentrations of pollutants.

\section{Introduction}

Formaldehyde $\left(\mathrm{CH}_{2} \mathrm{O}\right)$ is an oxygenated volatile organic compound (VOC) that plays an important role in the formation of ozone pollution in urban areas. Both primary sources (i.e. direct emissions from anthropogenic sources) and secondary sources (i.e. production in the atmosphere during oxidation of other, directly emitted VOCs) contribute to atmospheric concentrations of $\mathrm{CH}_{2} \mathrm{O}$. Most secondary production of $\mathrm{CH}_{2} \mathrm{O}$ is expected to occur during the atmospheric oxidation of ethene, propene and higher terminal alkenes, such as 1-butene, 1,3-butadiene and isoprene, but $\mathrm{CH}_{2} \mathrm{O}$ is additionally formed more slowly from the oxidation of alkanes and aromatic compounds. $\mathrm{CH}_{2} \mathrm{O}$ is lost from the atmosphere through photolysis, reaction with the hydroxyl radical $(\mathrm{OH})$, and deposition.

Quantifying the relative contribution of primary and secondary $\mathrm{CH}_{2} \mathrm{O}$ sources is crucial to developing effective ozone control strategies in urban areas. Photolysis of $\mathrm{CH}_{2} \mathrm{O}$ is an important source of $\mathrm{OH}$ radicals, which are the species that initiate atmospheric photo-oxidation, and serves as a fuel 
for the photochemical cycles that produce ozone. Accumulation of $\mathrm{CH}_{2} \mathrm{O}$ during nighttime hours from direct emissions could provide large $\mathrm{CH}_{2} \mathrm{O}$ concentrations at dawn that could initiate photochemistry earlier in the diurnal cycle than would be the case in their absence. Thus, emissions from primary sources are an attractive target for regulatory efforts designed to reduce urban ozone concentrations.

Urban sources of atmospheric $\mathrm{CH}_{2} \mathrm{O}$ have been investigated for decades. In Los Angeles in 1980 Grosjean (1982) measured concentrations as high as $48 \mathrm{ppbv}$, and reported measurements by others from the 1960 s showing that $\mathrm{CH}_{2} \mathrm{O}$ exceeded $100 \mathrm{ppbv}$ in the worst photochemical episodes in that city. Based upon the observed diurnal cycle, Grosjean (1982) concluded that both direct anthropogenic emissions and photochemical production made substantial contributions to ambient $\mathrm{CH}_{2} \mathrm{O}$ concentrations. A variety of statistical studies have attempted to quantify the relative amounts of ambient $\mathrm{CH}_{2} \mathrm{O}$ contributed by primary and secondary sources in several cities, including Vancouver ( $\mathrm{Li}$ et al., 1997), Houston (Friedfeld et al., 2002; Rappenglück et al., 2010; and Buzcu Guven and Olaguer, 2011) and Mexico City (Garcia et al., 2006). More generally, many different approaches have estimated the relative emissions of VOCs based upon their measured ambient concentrations. Only relatively few of these approaches (e.g. de Gouw et al., 2005; Liu et al., 2009) have explicitly accounted for the different rates of loss and, in the case of secondary species, formation of the VOCs. We will see here that properly accounting for loss and formation rates are particularly important for determining sources of $\mathrm{CH}_{2} \mathrm{O}$ in particular and secondary products in general.

The quantification of primary and secondary formaldehyde sources is particularly important in Houston, Texas, which is characterized by strongly elevated atmospheric $\mathrm{CH}_{2} \mathrm{O}$ concentrations (Wert et al., 2003; Ryerson et al., 2003; Martin et al., 2004). Houston is home to a very large industrial sector associated with petrochemical and petroleum refining activity, and these industrial activities are associated with the elevated $\mathrm{CH}_{2} \mathrm{O}$ concentrations. Given this industrial activity, the relative contributions from primary and secondary sources may be significantly different from most urban areas. Indeed, Olaguer et al. (2009) have argued that primary emissions from this industrial sector may make large contributions to ambient $\mathrm{CH}_{2} \mathrm{O}$, and thus should be identified, quantified and controlled.

In this work, we present analytical methods for quantifying both primary and secondary sources of $\mathrm{CH}_{2} \mathrm{O}$. The major primary sources of $\mathrm{CH}_{2} \mathrm{O}$ that have been suggested to be important in Houston-Galveston-Brazoria (HGB) are motor vehicles and the area's industrial facilities. Primary emissions from the industrial facilities are derived from direct flux measurements, and those from the vehicle fleet are derived from measured ambient $\mathrm{CH}_{2} \mathrm{O}$ to $\mathrm{CO}$ ratios under conditions dominated by vehicle emissions, combined with emission inventory estimates for vehicle $\mathrm{CO}$ emissions. The secondary sources of $\mathrm{CH}_{2} \mathrm{O}$ in $\mathrm{HGB}$ are production from primary emissions of parent VOCs emitted from these same anthropogenic sources, as well as VOCs of biogenic origin. Photochemical oxidation initiated by $\mathrm{OH}$ during daytime is expected to dominate this secondary production, but nighttime oxidation initiated by ozone $\left(\mathrm{O}_{3}\right)$ or the nitrate radical $\left(\mathrm{NO}_{3}\right)$ reacting with those emitted VOCs also contributes. The amount of $\mathrm{CH}_{2} \mathrm{O}$ produced by secondary sources is derived from the estimated yield of $\mathrm{CH}_{2} \mathrm{O}$ from reacted VOCs combined with emission inventory estimates of industrial and vehicle VOC emissions. Although our primary goal is to provide a quantitative analysis of $\mathrm{CH}_{2} \mathrm{O}$ emitted by primary sources and formed from secondary sources within the HGB ozone nonattainment area, the approach presented here is applicable to other urban areas and to other photochemical species.

The following section describes the data sets utilized in this paper, and Sects. 3 and 4 address emissions from petrochemical facilities and on-road vehicle emissions. Section 5 compares our results to other analyses and discusses the reasons for the divergent results, and Sect. 6 discusses the results and presents conclusions.

\section{Data sets}

The analysis presented here is based upon archived data sets that have been described elsewhere; only brief introductions and references to these descriptions are given here. NOAA conducted two airborne studies in the HGB region during the TexAQS 2000 (Ryerson et al., 2003; Wert et al., 2003) and TexAQS 2006 (Washenfelder, et al., 2010; Peischl et al., 2010) field studies; those data are available at http: //esrl.noaa.gov/csd/tropchem/. The aircraft platforms were the NCAR Electra in 2000 and the NOAA WP-3D in 2006. Airborne $\mathrm{CH}_{2} \mathrm{O}$ concentrations were acquired by NCAR employing tunable infrared laser absorption spectroscopy. During the 2000 study a tunable diode laser absorption spectrometer described by Wert et al. (2003) was employed, while the 2006 study employed a tunable difference frequency generation laser absorption spectrometer, as described by Weibring et al. (2007). Both instruments provided 1-s to 10$\mathrm{s} \mathrm{CH}_{2} \mathrm{O}$ measurements. Both aircraft campaigns included $1 \mathrm{~Hz}$ measurements of $\mathrm{O}_{3}$, nitric oxide (NO), nitrogen dioxide $\left(\mathrm{NO}_{2}\right)$ total reactive nitrogen $\left(\mathrm{NO}_{\mathrm{y}}\right)$, carbon monoxide (CO), sulfur dioxide $\left(\mathrm{SO}_{2}\right)$, and carbon dioxide $\left(\mathrm{CO}_{2}\right)$ (Ryerson et al., 1998, 1999, 2000; Holloway et al., 2000; Daube et al., 2002). Speciated VOCs were measured by gas chromatography (GC) of whole air samples acquired during each flight (Schauffler et al., 1999). Both aircraft campaigns included speciated VOC measurements by proton transfer reaction mass spectrometry (PTR-MS) (de Gouw and Warneke, 2007), and the 2006 field campaign included ethene $\left(\mathrm{C}_{2} \mathrm{H}_{4}\right)$ measurements at $5 \mathrm{~s}$ resolution with laser photoacoustic spectroscopy (LPAS) (de Gouw et al., 2009). Parrish et al. (2009) give additional details of the 2006 measurements. 
Chalmers University of Technology equipped a mobile van with Solar Occultation Flux (SOF) and mobile Differential Optical Absorption Spectroscopy (DOAS) instrumentation (Mellqvist, 1999; Rivera et al., 2010; Mellqvist et al., 2010a) to measure vertical columns of $\mathrm{CH}_{2} \mathrm{O}$, ethene, propene, and other VOCs in 2006 and in 2009. The SOF technique is based on open path Fourier Transform Infrared (FTIR) Spectroscopy using direct solar radiation as the light source, while the mobile DOAS is an open path system with scattered solar radiation as the light source. Installation in a mobile van allows continuous column concentration measurements to be performed while transecting an emission plume. These measurements, together with measured position and wind speed, make it possible to calculate emission fluxes in the plume. The accuracy of these flux determinations is estimated to be on the order of $30 \%$, primarily due to the uncertainty of the wind speed. The SOF results are available from Mellqvist et al. (2010b).

The University of Houston conducted extensive measurements at Moody Tower, a site on the top of a $65 \mathrm{~m}$ building in Houston, Texas during the TexAQS-II radical and aerosol measurement project (TRAMP) (Lefer and Rappenglück, 2010), which was a component of the second Texas Air Quality Study (TexAQS II) (Parrish et al., 2009). Lefer and Rappenglück (2010) and references therein describe the measurements including $\mathrm{CH}_{2} \mathrm{O}, \mathrm{CO}, \mathrm{O}_{3}, \mathrm{NO}_{\mathrm{y}}$, and the photolysis rate of $\mathrm{NO}_{2}\left(j \mathrm{NO}_{2}\right)$. The analysis in the present paper utilizes the $\mathrm{CH}_{2} \mathrm{O}$ (measured by Hantzsch reaction fluorescence) and $\mathrm{CO}$ (measured by Gas Filter Correlation) data. The measurements were conducted from 13 August to 2 October 2006. The results reported here are based on 10-s averaged data that were provided to us by the TRAMP measurement team on 23 May 2008.

Baylor University deployed a Piper Aztec aircraft in the HGB region during the summer of 2006 (Baylor University, 2009; Olaguer et al., 2009). Measurements included $\mathrm{CH}_{2} \mathrm{O}$ (measured by Hantzsch reaction fluorescence), $\mathrm{O}_{3}$, $\mathrm{NO}, \mathrm{NO}_{2}, \mathrm{NO}_{\mathrm{y}}, \mathrm{CO}$, and VOCs (measured by canister sampling with gas chromatograph/flame ionization detection analysis). The data are available from the Texas Environmental Research Consortium (TERC) website: http: //projects.tercairquality.org/AQR/H063.

\section{Formaldehyde fluxes from petrochemical facilities in HGB}

In this section, we quantify the flux of secondary $\mathrm{CH}_{2} \mathrm{O}$ formed during the atmospheric oxidation of VOCs emitted from the petrochemical facilities in the HGB region, and compare it to the flux of primary $\mathrm{CH}_{2} \mathrm{O}$ emitted from these same facilities. The focus here is on the routine emissions that occur on a daily basis. It is much more difficult to address extraordinary, sporadic events, but some comments concerning literature reports of such events will be provided at the end of this section.

\subsection{Quantification of formaldehyde formed from oxidation of petrochemical HRVOC emissions}

Analysis of observations made during the TexAQS 2000 study (Ryerson et al., 2003; Wert et al., 2003; Kleinman et al., 2002, 2003; Daum et al., 2003) established that the petrochemical industrial facilities in Houston consistently emit large amounts of VOCs and oxides of nitrogen $\left(\mathrm{NO}_{\mathrm{x}}\right.$ $=\mathrm{NO}+\mathrm{NO}_{2}$ ) to the atmosphere. The VOCs characteristically include especially large concentrations of highly reactive volatile organic compounds (HRVOCs), in particular the alkenes ethene and propene. During daytime, these emissions produce plumes of elevated $\mathrm{O}_{3}$ concentrations downwind from the sources, and analysis confirmed that the initial hydrocarbon reactivity in the petrochemical source plumes is primarily due to the alkenes. These plumes also contain high (as much as $>30 \mathrm{ppbv}$ ) concentrations of $\mathrm{CH}_{2} \mathrm{O}$ formed as a secondary product of the HRVOC oxidation (Wert et al., 2003). Figure 1 shows one example of such a plume observed downwind of the Houston Ship Channel (HSC).

The evolution of the relationship between $\mathrm{O}_{3}$ and $\mathrm{CH}_{2} \mathrm{O}$ measured aboard the NCAR Electra in the 27 August 2000 plume is illustrated in Fig. 1 and quantitatively examined in Fig. 2. The flight involved multiple, crosswind transects flown upwind and downwind from HSC. The molar enhancement ratio of $\mathrm{CH}_{2} \mathrm{O}$ to $\mathrm{O}_{3}$ produced in the plume at a particular downwind transect is given by the slope of the linear correlation between the measurements made during that transect. In Fig. 2 all linear correlations are required to pass through the estimated background concentrations of $\mathrm{CH}_{2} \mathrm{O}$ and $\mathrm{O}_{3}$ appropriate for that day: $0.5 \mathrm{ppbv} \mathrm{CH}_{2} \mathrm{O}$ (the concentration in background air over the Central Gulf of Mexico, Gilman et al., 2009) and 31.7 ppbv $\mathrm{O}_{3}$ (the $\mathrm{O}_{3}$ concentration at $\mathrm{CH}_{2} \mathrm{O}=0.5$ ppbv calculated from the $\mathrm{CH}_{2} \mathrm{O}-\mathrm{O}_{3}$ correlation for the farthest upwind transect at $29.0^{\circ} \mathrm{N}$ ). Downwind of HSC the concentrations of both species increased rapidly, and by the second transect at $\sim 24 \mathrm{~km}$ downwind $\left(30.0^{\circ} \mathrm{N}\right) \mathrm{CH}_{2} \mathrm{O}$ reached its maximum concentration and the two species were well correlated $\left(r^{2}=0.88\right)$. On subsequent transects, $\mathrm{O}_{3}$ reached its maximum concentration, but the ratio of $\mathrm{CH}_{2} \mathrm{O}$ to $\mathrm{O}_{3}$ continually decreased through the farthest downwind plume transect while the correlation continued to increase to a maximum of $r^{2}=0.94$. Figure 3 summarizes the $\mathrm{CH}_{2} \mathrm{O}$ to $\mathrm{O}_{3}$ ratios at the downwind transects and compares the 27 August flight to a second flight conducted under similar conditions on 28 August (see Fig. 8 of Ryerson et al., 2003 and Figs. 5 and 6 of Wert et al., 2003).

The photochemical evolution of $\mathrm{CH}_{2} \mathrm{O}$ in the plume illustrated in Figs. 2 and 3 suggests a useful approach for calculating the flux of secondary $\mathrm{CH}_{2} \mathrm{O}$ formed in plumes downwind of petrochemical facilities. The peak $\mathrm{CH}_{2} \mathrm{O}$ concentration is reached early in the plume transport since the daytime 

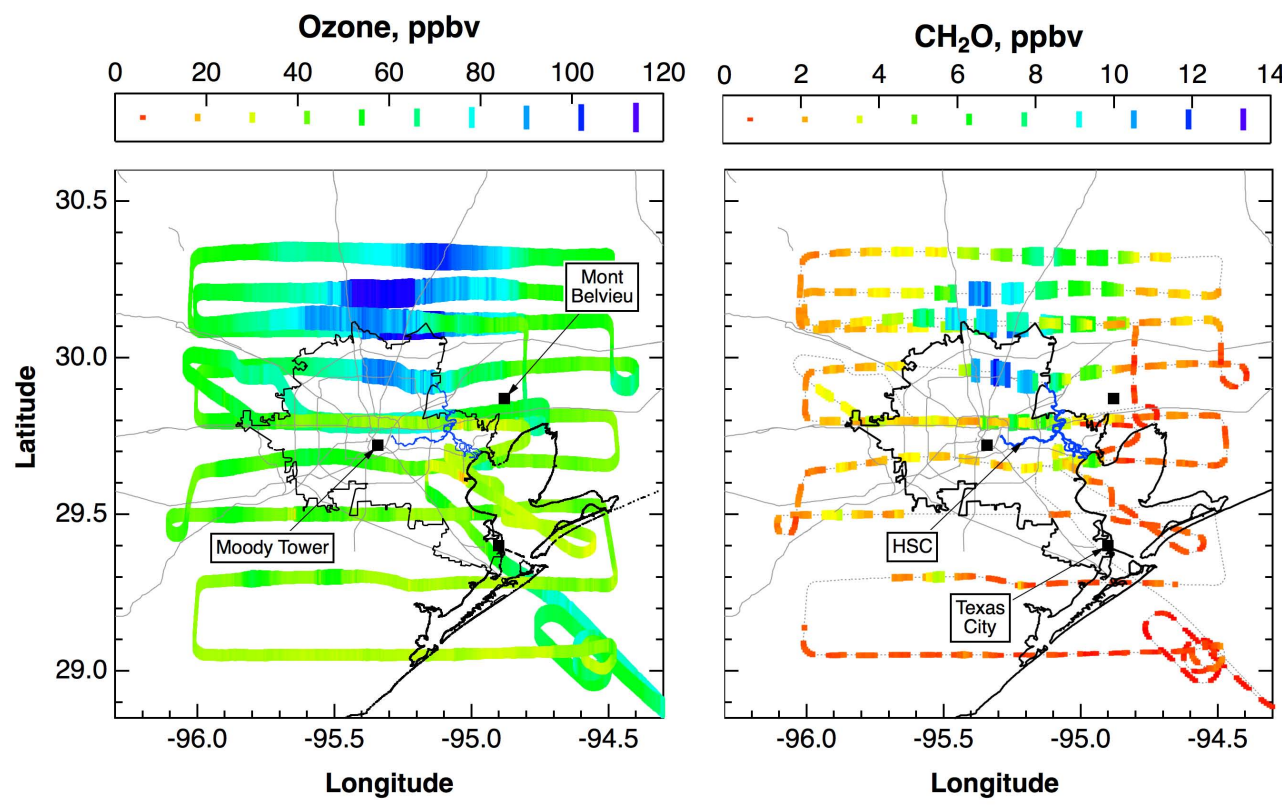

Fig. 1. Distributions of ozone (left) and formaldehyde (right) downwind of the HSC measured by the Electra aircraft during TexAQS 2000. The data were collected between 12:00 and 18:00 local standard time, and are plotted on the 27 August 2000 flight track, with the symbols sized and color-coded according to the measured mixing ratios of the respective species as indicated by the keys above each plot. During this flight, measured winds were southerly (wind direction $=162 \pm 17^{\circ}$ ) and steady (wind speed $=5.4 \pm 1.5 \mathrm{~m} \mathrm{~s}^{-1}$ ), where standard deviations of the respective quantities are indicated. Text boxes with arrows indicate approximate locations of specific petrochemical complexes and a measurement site referred to in the text.

lifetimes of its HRVOC precursors are short (3-8 $\mathrm{h}$ for ethene and $1-2.5 \mathrm{~h}$ for propene, Wert et al., 2003). This slows $\mathrm{CH}_{2} \mathrm{O}$ production as transport proceeds. In addition, the lifetime of $\mathrm{CH}_{2} \mathrm{O}$ is also short ( 3 to $4 \mathrm{~h}$ in the sunlit lower troposphere, Seinfeld and Pandis, 1998). This leads to a rapid decrease of the $\mathrm{CH}_{2} \mathrm{O}$ concentration when production slows.

Given these constraints, the total quantity of secondary $\mathrm{CH}_{2} \mathrm{O}$ formed from primary HRVOC emissions can be calculated from the product of the total emissions times the yield of $\mathrm{CH}_{2} \mathrm{O}$ produced during the atmospheric oxidation of these alkenes. The total HRVOC emissions in HGB are available from emission inventories and from direct ambient measurements of HRVOC fluxes in the downwind plumes. However, since the available inventories generally underestimate the alkene emissions from these facilities by large factors, we cannot directly use the 2005 National Emission Inventory (NEI) (Ryerson et al., 2003; de Gouw et al., 2009, Mellqvist et al., 2010a). Instead we use an inventory (Brioude et al., 2011; Kim et al., 2011) that has been modified on a facilityby-facility basis to agree with the measured fluxes of ethene and propene (Mellqvist et al., 2010a). Since the lifetime of the alkenes are generally shorter than the time for transport of air masses out of $\mathrm{HGB}$, this calculation will provide a realistic estimate of the secondary source of $\mathrm{CH}_{2} \mathrm{O}$ from the petrochemical facilities.

On this basis the results of the quantification of the secondary $\mathrm{CH}_{2} \mathrm{O}$ flux from specific petrochemical facilities and the total HGB area are given in Table 1. Assuming that $\mathrm{OH}$ is the primary oxidant of the alkenes, Seinfeld and Pandis (1998) give the product yields of 1.44 molecules $\mathrm{CH}_{2} \mathrm{O}$ per molecule ethene and 0.86 molecules $\mathrm{CH}_{2} \mathrm{O}$ per molecule propene. The product of the emission flux of each alkene times the product yield of $\mathrm{CH}_{2} \mathrm{O}$ from that alkene yields an estimate of the secondary $\mathrm{CH}_{2} \mathrm{O}$ formed from that alkene. A sum over the emitted alkenes gives an estimate of the total secondary $\mathrm{CH}_{2} \mathrm{O}$. Table 1 gives the alkene fluxes directly measured from specific facilities, as well as the integration over the entire HGB region (latitude 28.9 to $30.6^{\circ} \mathrm{N}$; longitude 94.4 to $96.2^{\circ} \mathrm{W}$ ) from the emission inventory. Table 1 also gives the flux of secondary $\mathrm{CH}_{2} \mathrm{O}$ that would result from the atmospheric oxidation of those primary alkene emission fluxes.

In the above paragraphs we have formulated a simple approach to estimating the total average production of secondary $\mathrm{CH}_{2} \mathrm{O}$ from petrochemical facilities in the HGB region. This approach is based upon two assumptions: first, the total average $\mathrm{CH}_{2} \mathrm{O}$ production rate is well-approximated by the rate of $\mathrm{CH}_{2} \mathrm{O}$ formed by complete $\mathrm{OH}$ oxidation of the ethene and propene emitted by those facilities. Second, the $\mathrm{CH}_{2} \mathrm{O}$ yields from ethene and propene are constant at 1.44 and 0.86 molecules $\mathrm{CH}_{2} \mathrm{O}$ per molecule ethene and propene, respectively. The quantification of the uncertainties in this approach is difficult. The $\mathrm{CH}_{2} \mathrm{O}$ yields from $\mathrm{OH}$ oxidation are well known, but the emissions of ethene and propene are 
Table 1. Summary of the measured and inventory average primary emission fluxes and estimated secondary formation rate of $\mathrm{CH}_{2} \mathrm{O}$ from

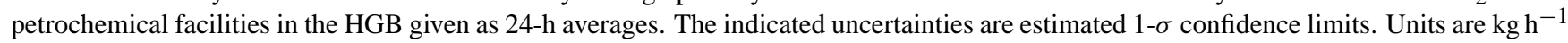
except as noted.

\begin{tabular}{lllll}
\hline Area & Primary Ethene & Primary Propene & Secondary $\mathrm{CH}_{2} \mathrm{O}^{1}$ & Primary $\mathrm{CH}_{2} \mathrm{O}$ \\
\hline HSC & $500 \pm 54^{2}$ & $642 \pm 108^{2}$ & $1165 \pm 490$ & $45 \pm 21^{2}$ \\
Mont Belvieu & $444 \pm 174^{2}$ & $303 \pm 189^{2}$ & $871 \pm 520$ & $17 \pm 7^{2}$ \\
Texas City & $122 \pm 41^{2}$ & $54 \pm 22^{2}$ & $221 \pm 120$ & $22 \pm 5^{2}$ \\
Total HGB & $2550^{3}$ & $4250^{3}$ & $6550 \pm 2620$ & $317^{3}$ \\
\hline Total $\mathrm{HGB}^{4}$ & 91 & 101 & $220 \pm 90$ & 10.6 \\
\hline
\end{tabular}

\footnotetext{
${ }^{1}$ Estimated from product of the fluxes of ethene and propene multiplied by the $\mathrm{CH}_{2} \mathrm{O}$ product yield of the respective alkene.

2 Measured emissions with estimated 1- $\sigma$ uncertainties (Mellqvist et al., 2010b).

${ }^{3}$ Emission inventory (Kim et al., 2011) integrated over the HGB.

${ }^{4}$ Units in $\mathrm{kmole}^{-1}$.
}

uncertain. To minimize this uncertainty, we have based our analysis upon inventories supported by direct measurements of fluxes. However, a fraction of ethene and propene may not react before leaving HGB, leading to an overestimate. On the other hand, the contribution from oxidation of emissions of heavier alkenes, alkanes and aromatics is neglected, which would lead to an underestimate. Wert et al. (2003) present an analysis of the " $\mathrm{CH}_{2} \mathrm{O}$ production potential" of the individual VOCs measured in specific atmospheric samples. This $\mathrm{CH}_{2} \mathrm{O}$ production potential gives the total rate at which $\mathrm{CH}_{2} \mathrm{O}$ is formed from all measured VOCs during oxidation by $\mathrm{OH}$ radicals. For the eight most concentrated (i.e. least photochemically processed) VOC samples collected over industrial regions in $\mathrm{HGB}$, the terminal alkenes, largely ethene and propene, on average, composed $95 \%$ of total $\mathrm{CH}_{2} \mathrm{O}$ production potential. However, this percentage gives an instantaneous picture of $\mathrm{CH}_{2} \mathrm{O}$ formation early in the oxidation of the plume, while the total $\mathrm{CH}_{2} \mathrm{O}$ production derived above is an integration over the time that the emissions remain in the $\mathrm{HGB}$ region. It must also be noted that $\mathrm{NO}_{3}$ and $\mathrm{O}_{3}$ also are important oxidants of alkenes heavier than ethene (Brown et al., 2011); however these oxidation pathways are less important than $\mathrm{OH}$, and they also produce $\mathrm{CH}_{2} \mathrm{O}$ with similar yields. In summary, the above quantification of secondary production likely is an underestimate for daytime, when contributions from heavier alkenes, alkanes and aromatics are neglected, but an overestimate for nighttime when chemical processing is slower, and some fraction of the emissions can be transported out of HGB before reacting. There are also uncertainties in the $\mathrm{CH}_{2} \mathrm{O}$ yield from the oxidation of the alkenes by $\mathrm{NO}_{3}$ and $\mathrm{O}_{3}$. Overall, the approach has been designed so that some uncertainties likely compensate for others. We judge that a conservative estimate for the 1- $\sigma$ uncertainty of the quantification of the rate of secondary $\mathrm{CH}_{2} \mathrm{O}$ formation is $\pm 40 \%$. This value is reflected in the uncertainties indicated in Table 1.

\subsection{Direct measurement of the primary formaldehyde flux from petrochemical facilities}

The most direct measurement of the primary flux of $\mathrm{CH}_{2} \mathrm{O}$ from industrial facilities in HGB is that reported by Mellqvist et al. (2010b) and Johansson et al. (2010), who deployed a mobile van just downwind of specific industrial areas to measure emission fluxes in the plumes from the facilities. Table 1 presents a summary of measurements conducted in 2009 , which found relatively small fluxes of $\mathrm{CH}_{2} \mathrm{O}$ immediately downwind of the industrial facilities. Mellqvist et al. (2010b) argue that these $\mathrm{CH}_{2} \mathrm{O}$ fluxes represent mostly primary emissions, because the measurements were made so close to the facility that transport times were short enough that secondary formation was assumed to contribute little to the observed $\mathrm{CH}_{2} \mathrm{O}$ fluxes.

Mellqvist et al. (2010b) and Johansson et al. (2010) present one flux measurement that allows our determination of the quantity of secondary $\mathrm{CH}_{2} \mathrm{O}$ formation to be tested. On 20 May 2009 under easterly winds they measured the flux of alkenes and $\mathrm{CH}_{2} \mathrm{O}$ in the coalesced plume from the HSC and Mont Belvieu areas during a transect on the west side of the HSC (see Fig. 58 of Mellqvist et al., 2010b). The transport time was sufficient ( $\sim 2-3 \mathrm{~h}$ from Mont Belvieu) for substantial photochemical production of $\mathrm{CH}_{2} \mathrm{O}$ to have proceeded. The measured $\mathrm{CH}_{2} \mathrm{O}$ flux was about $1200 \mathrm{~kg} \mathrm{~h}^{-1}$, and the plume still had a significant flux of unreacted alkenes (e.g. $490 \mathrm{~kg} \mathrm{~h}^{-1}$ ethene). When these unreacted alkenes do react, the ultimate total flux of $\mathrm{CH}_{2} \mathrm{O}$ is expected to be at least $1960 \mathrm{~kg} \mathrm{~h}^{-1}$, which agrees to within $4 \%$ with the combined $2040 \mathrm{~kg} \mathrm{~h}^{-1}$ secondary source calculated by summing the separate contributions from HSC and Mont Belvieu in Table 1.

A comparison of primary and secondary $\mathrm{CH}_{2} \mathrm{O}$ fluxes from the petrochemical facilities is included in Table 1. Summing over the three petrochemical industrial areas, $4 \pm 2 \%$ of the $\mathrm{CH}_{2} \mathrm{O}$ flux is of primary origin and $96 \pm 2 \%$ is of secondary origin, produced during photochemical oxidation 


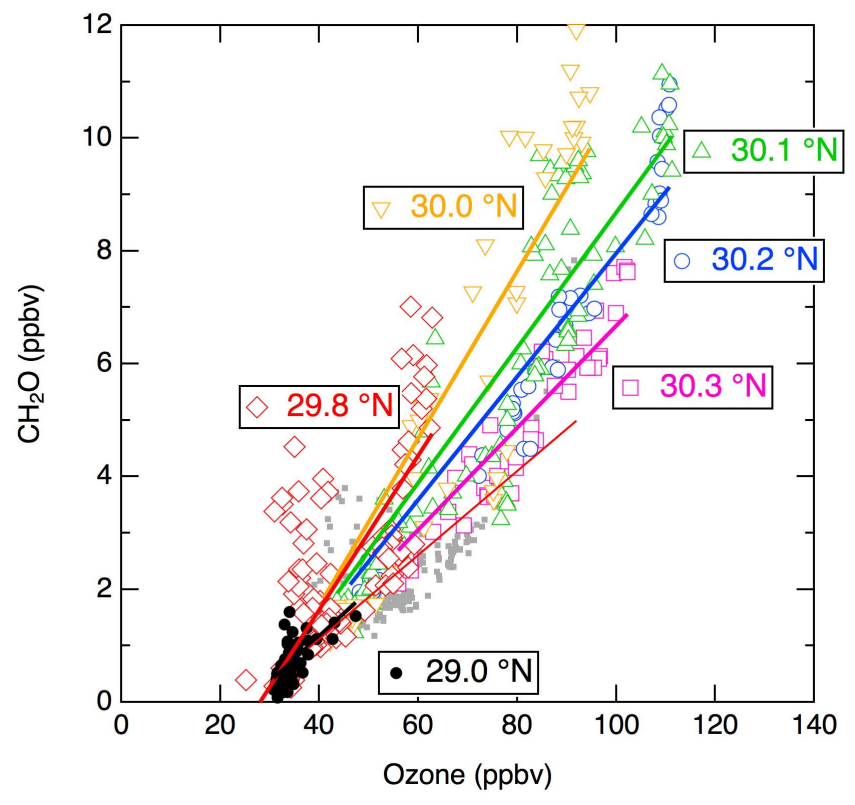

Fig. 2. Relationship of formaldehyde versus ozone mixing ratios measured during the 27 August 2000 flight. The data collected at one upwind $\left(29.0^{\circ} \mathrm{N}\right.$ latitude) and five downwind transects from HSC (east of $-95.5^{\circ}$ longitude) are shown by different symbols color-coded according to latitude as indicated in the annotations. All other data are shown as grey dots. Linear least squares fits to the data from each transect are shown also color-coded. These fits all pass through the background mixing ratios of $\mathrm{O}_{3}(31.7 \mathrm{ppbv})$ and $\mathrm{CH}_{2} \mathrm{O}(0.5 \mathrm{ppbv})$ as explained in text.

of primary alkene emissions. We take this relative primarysecondary partitioning to be characteristic of the entire petrochemical sources of $\mathrm{CH}_{2} \mathrm{O}$ in $\mathrm{HGB}$.

\subsection{Sporadic formaldehyde emission events from petrochemical facilities}

Olaguer et al. (2009) have focused attention on sporadic episodes in the HGB area characterized by very high reported concentrations of $\mathrm{CH}_{2} \mathrm{O}$ up to $52 \mathrm{ppbv}$ (Eom et al., 2008). They argue that direct primary emissions can possibly explain these high concentrations. Here we briefly discuss the expected signature of concentrations of trace species within plumes of primary $\mathrm{CH}_{2} \mathrm{O}$ emissions, and then examine two episodes that have received particular attention (Olaguer et al., 2009). The goal is to determine if secondary formation alone is adequate to explain the observed $\mathrm{CH}_{2} \mathrm{O}$ concentrations, or if there is substantial evidence for significant sporadic episodes of primary $\mathrm{CH}_{2} \mathrm{O}$ emissions.

A unique signature is expected for measurements made within a fresh plume of primary $\mathrm{CH}_{2} \mathrm{O}$ emissions. Initially upon emission of primary $\mathrm{CH}_{2} \mathrm{O}$ the enhanced $\mathrm{CH}_{2} \mathrm{O}$ concentrations would not be accompanied by enhanced $\mathrm{O}_{3}$ concentrations. In contrast, secondary production of $\mathrm{CH}_{2} \mathrm{O}$ is generally accompanied by production of $\mathrm{O}_{3}$. Plumes with

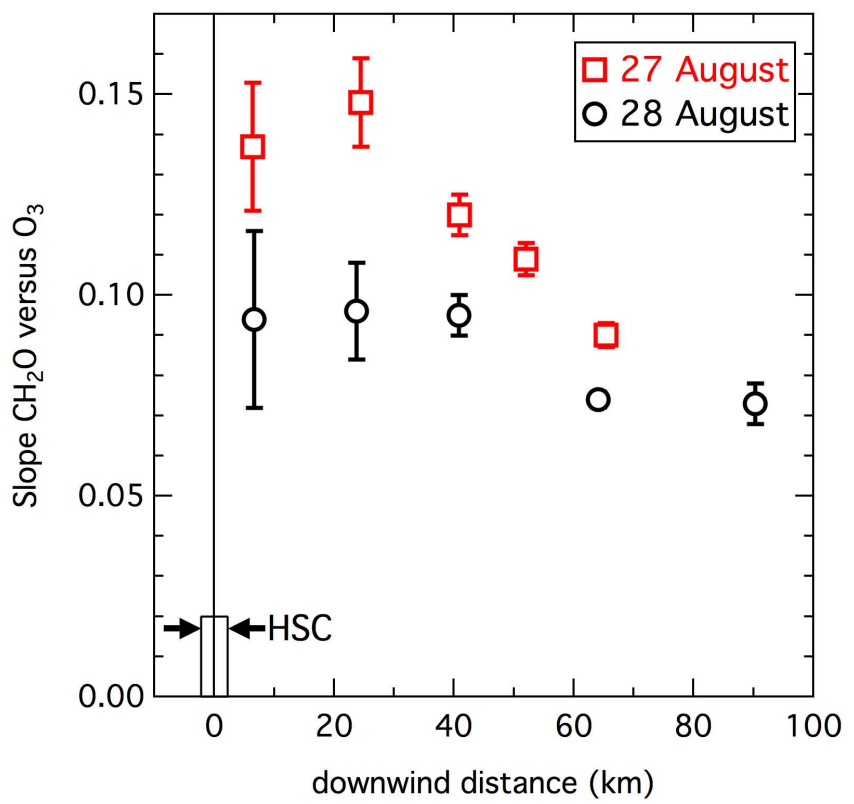

Fig. 3. Dependence of the slope with $95 \%$ confidence limits of the $\mathrm{CH}_{2} \mathrm{O}$ versus $\mathrm{O}_{3}$ relationship as a function of downwind distance from HSC. The 27 August 2000 data are from the linear regressions illustrated in Fig. 2; the 28 August 2000 data are from a similar analysis of a second flight conducted under similar meteorological conditions. The bar with arrows indicates the location and approximate width of the HSC industrial region. The farthest downwind transect corresponds to about $6 \mathrm{~h}$ transport time.

significantly enhanced $\mathrm{CH}_{2} \mathrm{O}$ concentrations without correlated $\mathrm{O}_{3}$ concentration enhancements were not encountered in either of the two NOAA airborne field campaigns conducted during TexAQS 2000 (Wert et al., 2003; Ryerson et al., 2003) and TexAQS 2006 (Washenfelder, et al., 2010). Figure 2 shows the relationship between $\mathrm{CH}_{2} \mathrm{O}$ and $\mathrm{O}_{3}$ found on 27 August 2000, which was typical of that found in all the research flights conducted by NOAA during the two TexAQS studies. The number of coincident $\mathrm{CH}_{2} \mathrm{O}$ and $\mathrm{O}_{3}$ data points (14031 10-s averages and 1466241 -s averages in 2000 and 2006, respectively) represent over $14000 \mathrm{~km}$ flight distance in each study from 14 days in 2000 and 12 days in 2006. Many individual plumes were examined during the analysis performed for publications based on these data (Wert et al., 2003; Ryerson et al., 2003; Washenfelder, et al., 2010). The TexAQS 2006 study included nighttime flights (Brown et al., 2009), when primary emissions of $\mathrm{CH}_{2} \mathrm{O}$ would be particularly obvious, but evident plumes of primary $\mathrm{CH}_{2} \mathrm{O}$ emissions were not encountered. If concentrated plumes (i.e. several ppbv enhancements) of fresh $\mathrm{CH}_{2} \mathrm{O}$ primary emissions are present in the HGB region, they were not encountered in either of these aircraft studies.

It is, of course, impossible to prove that primary emissions never play a significant or even a dominant role in some isolated episodes. A plume of primary $\mathrm{CH}_{2} \mathrm{O}$ emissions 
released in daytime would be expected to produce significant amounts of $\mathrm{O}_{3}$ from the photochemical processing of $\mathrm{CH}_{2} \mathrm{O}$ as long as sufficient $\mathrm{NO}_{\mathrm{x}}$ is also present, so a plume of primary $\mathrm{CH}_{2} \mathrm{O}$ emissions would soon lose its unique signature. However, it is possible to investigate if secondary formation alone is adequate to explain specific observed episodes. Here we examine two episodes that have received particular attention.

During a morning flight on 31 August 2006, the Baylor Aztec aircraft repeatedly sampled a plume over and downwind of the HSC. This plume contained $\mathrm{CH}_{2} \mathrm{O}$ concentrations higher than the instrument could quantify ( $\sim 9 \mathrm{ppbv})$, as well as high concentrations of a variety of primary species and ozone (see Supplement and Fig. 8 of Olaguer et al., 2009). Examination of the original data set (Baylor University, 2009) demonstrates that this plume represented a very complicated air mass with separate parts of the plume showing markedly different ratios of the primary pollutants $\mathrm{NO}_{\mathrm{x}}$, $\mathrm{CO}$ and $\mathrm{SO}_{2}$. It is also evident that relatively fresh emissions (i.e. those with a large fraction of $\mathrm{NO}_{\mathrm{y}}$ still present as $\mathrm{NO}_{\mathrm{x}}$ ) were mixing with aged pollution, as indicated by high $\mathrm{O}_{3}$ concentrations approaching $200 \mathrm{ppbv}$, which is the highest $\mathrm{O}_{3}$ observed by the Baylor Aztec during 2006. The time resolution of the $\mathrm{CH}_{2} \mathrm{O}$ instrument $(\sim 1 \mathrm{~min})$ was not adequate to resolve the rapid concentration changes encountered by the aircraft. Hence, it is undetermined whether the high observed $\mathrm{CH}_{2} \mathrm{O}$ concentrations were associated with the fresh emissions or the aged pollution. It is apparent however, that the observed high $\mathrm{O}_{3}$ concentrations are consistent with very high concentrations of secondary $\mathrm{CH}_{2} \mathrm{O}$; for example Wert et al. (2003) report $\mathrm{CH}_{2} \mathrm{O}>30 \mathrm{ppbv}$ in a plume with $\mathrm{O}_{3} \sim 150 \mathrm{ppbv}$. Thus, the measurements reported by the Baylor Aztec in the 31 August 2006 plume do not provide strong evidence for primary emissions of $\mathrm{CH}_{2} \mathrm{O}$ as the main source of this plume. Rivera et al. (2010) report the flux of $\mathrm{CH}_{2} \mathrm{O}$ from the $\mathrm{HSC}$ on this same day, and conclude that its source was predominately secondary production from VOC emissions within HSC.

Eom et al. (2008) report the observation of a $\mathrm{CH}_{2} \mathrm{O}$ plume during the morning of 27 September 2006 at the Lynchburg Ferry USEPA site in Baytown, TX. This plume reached a maximum concentration of $52 \mathrm{ppbv}$, which is reportedly the maximum ambient concentration of $\mathrm{CH}_{2} \mathrm{O}$ ever observed in the HGB region. There was no conclusive evidence for the source of this $\mathrm{CH}_{2} \mathrm{O}$. Based upon poor correlation with $\mathrm{O}_{3}$ and other arguments, the authors argue that primary $\mathrm{CH}_{2} \mathrm{O}$ emissions may have played a role. A definitive examination of the sources of $\mathrm{CH}_{2} \mathrm{O}$ in this (or any other) plume requires consideration of the recent transport of the sampled air parcel. Meteorological analyses (see Supplement) indicate that the air from the HGB region on 26 September was transported south over Galveston Bay and returned to the HGB area at the time that the 27 September plume was observed. The stagnation and recirculation transport pattern of this plume is ideal for accumulation of high $\mathrm{CH}_{2} \mathrm{O}$ concen- trations from secondary processing of the HRVOC emissions from the HSC. Until the transport and chemical processing that occurred in this plume are understood in detail, no definitive assignment of the source of $\mathrm{CH}_{2} \mathrm{O}$ in this plume is possible. In summary, no strong evidence has been presented for episodes of sporadic $\mathrm{CH}_{2} \mathrm{O}$ primary emissions from the petrochemical facilities in the HGB region.

\section{Formaldehyde fluxes from on-road vehicles in HGB}

In this section, we quantify the fluxes of primary $\mathrm{CH}_{2} \mathrm{O}$ emissions from on-road vehicles in the HGB region, and estimate the rate of secondary formation of $\mathrm{CH}_{2} \mathrm{O}$ during the atmospheric oxidation of the alkenes emitted by these vehicles.

\subsection{Determination of the primary emission flux from on-road vehicles}

To estimate the flux of primary $\mathrm{CH}_{2} \mathrm{O}$ from on-road vehicle emissions, we multiply the $\mathrm{CH}_{2} \mathrm{O}$ to $\mathrm{CO}$ emission ratio deduced from field observations in Houston by the total $\mathrm{CO}$ emission rate from on-road vehicles in HGB. This latter quantity is available from emission inventories constrained by ambient measurements. The $\mathrm{CH}_{2} \mathrm{O}$ to $\mathrm{CO}$ emission ratio is quantified from the relationship between the concentrations of these two species observed during the morning traffic peak. This time period is selected because traffic related sources can dominate the ambient $\mathrm{CH}_{2} \mathrm{O}$ concentrations, and the loss of $\mathrm{CH}_{2} \mathrm{O}$ from the atmosphere is minimized because $\mathrm{OH}$ levels are suppressed by high $\mathrm{NO}_{\mathrm{x}}$ concentrations and photolysis is still slow. The predominant source of $\mathrm{CO}$ in HGB is on-road vehicle emissions, so the ambient enhancement ratio of $\mathrm{CH}_{2} \mathrm{O}$ to $\mathrm{CO}$ is not affected by dilution. In the following, all emission ratios are expressed as molar ratios, not mass ratios.

A preliminary analysis prepared for the TexAQS II Rapid Science Synthesis (Cowling et al., 2007) estimated that the primary emissions of $\mathrm{CH}_{2} \mathrm{O}$ from mobile sources were, as an upper limit, 0.18 to $0.30 \%$ of the $\mathrm{CO}$ emissions. This estimate was based upon nighttime measurements made on the NOAA research vessel Ronald H. Brown and WP-3D aircraft (see Fig. E2 of Cowling et al., 2007). This estimate was deemed an upper limit, due to the possibility that the sampled air had been photochemically processed to at least some extent during the preceding daytime period, or that some fraction of the observed formaldehyde had been produced from nighttime secondary production through $\mathrm{O}_{3}$ or $\mathrm{NO}_{3}$ reaction with primary VOCs. These findings are broadly consistent with previous determinations of the $\mathrm{CH}_{2} \mathrm{O}$ to $\mathrm{CO}$ emission ratios of $\sim 0.2$ to $0.3 \%$ in Los Angeles (Grosjean, 1982), 0.10 to $0.14 \%$ in Denver, Colorado (Anderson et al., 1996), and $0.24 \%$ in Rome (Possanzini et al., 1996).

Rappenglück et al. (2010) report $\mathrm{CH}_{2} \mathrm{O}$ and $\mathrm{CO}$ measured at Moody Tower in Houston, Texas as part of the TRAMP 


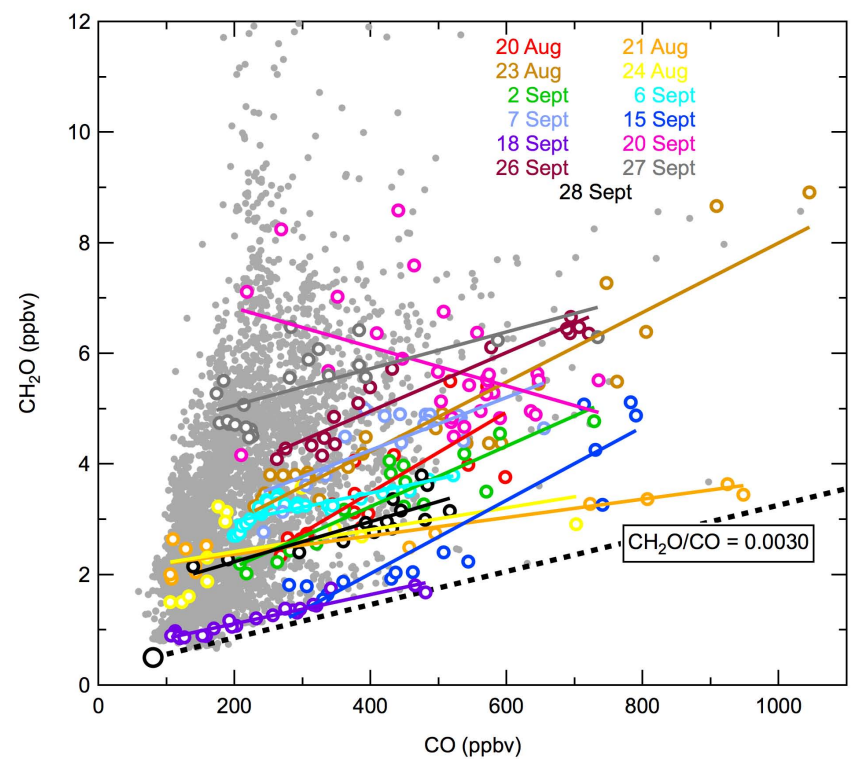

Fig. 4. Relationship between $\mathrm{CH}_{2} \mathrm{O}$ and $\mathrm{CO}$ observed at Moody Tower during TRAMP. Gray points include all data with $\mathrm{CH}_{2} \mathrm{O}$ mixing ratios $\leq 12$ ppbv. Small circles color-coded by date indicate the morning traffic peak data discussed further in the text. The solid colored lines indicate the linear, least-squares fits to the respective color-coded data. The large black circle indicates the Central Gulf of Mexico mixing ratios reported by Gilman et al. (2009), and the heavy, dotted black line indicates the expected mixing ratio enhancements from primary emissions of $\mathrm{CH}_{2} \mathrm{O}$ and $\mathrm{CO}$ in a ratio of $0.3 \%$.

study (Lefer and Rappenglück, 2010). As shown in Fig. 4, the relationship between the concentrations of these two species measured at all times of day is not well represented by a single linear correlation. Thus, sources other than direct emissions from the on-road vehicle fleet must be important. The large open circle and dotted black line in Fig. 4 show the $\mathrm{CH}_{2} \mathrm{O}-\mathrm{CO}$ relationship expected if background air from the Central Gulf of Mexico with $80 \mathrm{ppbv} \mathrm{CO}$ and $0.5 \mathrm{ppbv}$ $\mathrm{CH}_{2} \mathrm{O}$ (Gilman et al., 2009) were transported into HGB and impacted only by on-road vehicle emissions with a $\mathrm{CH}_{2} \mathrm{O}$ to $\mathrm{CO}$ emission ratio of $0.3 \%$. Virtually none of the Moody Tower data lies on this reference line, but it does define the lower envelope of the observed $\mathrm{CH}_{2} \mathrm{O}$ as a function of $\mathrm{CO}$.

To obtain the best estimate for the $\mathrm{CH}_{2} \mathrm{O}$ to $\mathrm{CO}$ emission ratio for on-road vehicles from the Moody Tower data set, we examine the correlation between these two species in the period before and during the morning traffic peak on individual days. The time window on each day is generally selected to include a pre-sunrise $\mathrm{CO}$ minimum, which represents the background air on that specific day to which the traffic emissions are added, and extend to the morning $\mathrm{CO}$ maximum. Only days with substantial CO enhancements (selected as peak CO exceeding $480 \mathrm{ppbv}$ ) are included in this evaluation. The color-coded points in Fig. 4 identify the 13 days

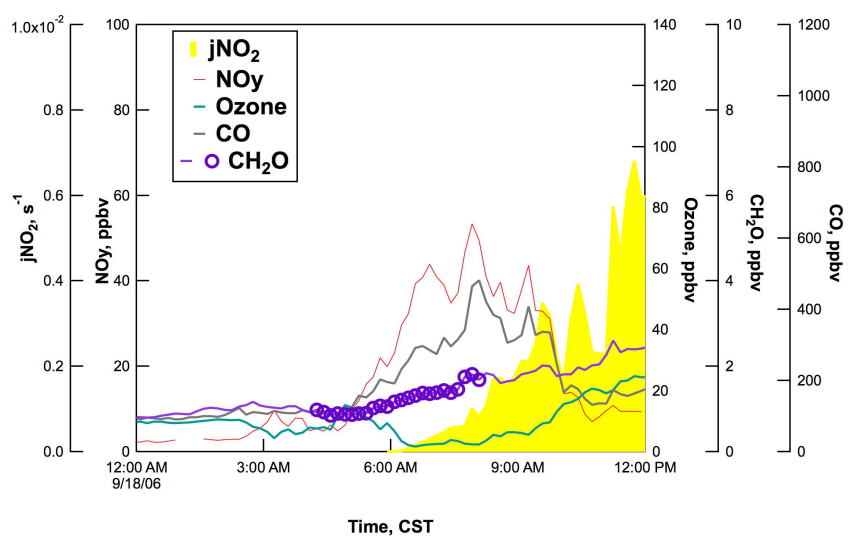

Fig. 5. Time series of the photolysis rate of $\mathrm{NO}_{2}$ and the mixing ratios of $\mathrm{NO}_{\mathrm{y}}, \mathrm{O}_{3}, \mathrm{CH}_{2} \mathrm{O}$ and $\mathrm{CO}$ observed during the morning of 18 September 2006 at Moody Tower. Small circles indicate the $\mathrm{CH}_{2} \mathrm{O}$ data for that day included in the linear regression illustrated in Fig. 4. Time is given as local standard time (CST).

during the TRAMP measurements when both $\mathrm{CH}_{2} \mathrm{O}$ and $\mathrm{CO}$ data were collected during the morning traffic peak, and the peak $\mathrm{CO}$ exceeded $480 \mathrm{ppbv}$.

Only one (18 September) of the 13 days with strong morning $\mathrm{CO}$ enhancements closely approximates the reference line in Fig. 4. That day was nearly ideal for evaluating the on-road vehicle emission ratio. During the entire preceding day (a Sunday) the wind remained southerly $\left(171 \pm 19^{\circ}\right.$; average \pm standard deviation) and brisk $\left(4.5 \pm 1.3 \mathrm{~m} \mathrm{~s}^{-1}\right)$. These winds brought relatively clean marine air to the Moody Tower site; for example, between midnight and 01:00 a.m. local standard time on 18 September, $\mathrm{O}_{3}=9.6 \pm 0.2 \mathrm{ppbv}, \mathrm{CO}=93 \pm 2 \mathrm{ppbv}$, $\mathrm{NO}_{\mathrm{y}}=2.4 \pm 0.2 \mathrm{ppbv}$, and $\mathrm{CH}_{2} \mathrm{O}=0.84 \pm 0.04$ ppbv. Between midnight and 06:00 a.m. the wind decreased in speed and rotated through westerly to northerly. By 06:00 a.m., winds were nearly calm allowing traffic emissions to accumulate in the resulting stagnant air. Since the petrochemical facilities lie generally east of the Moody Tower, no industrial emissions are expected to have impacted the measurements under such wind conditions (see Rappenglück et al., 2010). This expectation is supported by the measured $\mathrm{SO}_{2}$, which remained below $0.6 \mathrm{ppbv}$ during the predawn period. Figure 5 shows the gradual increase in $\mathrm{CO}, \mathrm{NO}_{\mathrm{y}}$ and $\mathrm{CH}_{2} \mathrm{O}$ during this time. (The Supplement gives similar plots for all 13 days.) From the predawn $\mathrm{CO}$ minimum to the morning maximum, $\mathrm{CH}_{2} \mathrm{O}$ was well correlated with $\mathrm{CO}$ $\left(r^{2}=0.92\right)$ with a linear regression slope of $0.0026 \pm 0.0003$ (average $\pm 95 \%$ confidence limit). This linear fit is included in Fig. 4. Since little day-to-day variability is expected in the HGB on-road vehicle fleet (at least for weekdays), the best estimate for the $\mathrm{CH}_{2} \mathrm{O}$ to $\mathrm{CO}$ emission ratio is $0.26 \pm 0.03 \%$, which agrees with the $0.18-0.30 \%$ upper limit estimate of Cowling et al. (2007). The $0.26 \pm 0.03 \%$ estimate is also an 
upper limit, since secondary production of $\mathrm{CH}_{2} \mathrm{O}$ from the VOCs co-emitted with $\mathrm{CH}_{2} \mathrm{O}$ by on-road vehicles are mixed with the primary emissions, even though the meteorological conditions on 18 September limit the time that the vehicle emissions remained in the atmosphere before measurement.

The slopes derived from the linear regressions for all 13 days with strong morning $\mathrm{CO}$ enhancements vary widely, which reflects variability of the influence of other sources (i.e. transport of petrochemical emission plumes containing secondary $\mathrm{CH}_{2} \mathrm{O}$ ) rather than variability in the vehicle fleet emissions themselves. Figure 4 shows the linear fits and Table 2 summarizes the slopes derived from those fits for all 13 days. Except for 18 September, the rush hour data all lie well above the reference line. This is attributed to transport of $\mathrm{CH}_{2} \mathrm{O}$ to Moody Tower from other sources within the HGB area. The variability of the slopes is attributed to the degree of correlation or anti-correlation of transported plumes with the morning traffic. Figure 6 illustrates two days that exemplify high correlation and high anti-correlation. On 15 September strong correlation $\left(r^{2}=0.85\right)$ between a transported plume with high $\mathrm{CH}_{2} \mathrm{O}$ concentrations and the morning $\mathrm{CO}$ maximum resulted in a relatively large slope $(0.0066 \pm 0.0017)$ due to the transport of enhanced $\mathrm{CH}_{2} \mathrm{O}$ concentrations (compare upper panel of Fig. 6 with Fig. 5, which use the same concentration scales.) In contrast, on 20 September, transported air with high $\mathrm{CH}_{2} \mathrm{O}$ concentrations reached Moody Tower throughout the early morning period, with the peak arriving before the $\mathrm{CO}$ traffic peak, which resulted in a negative correlation with $\mathrm{CO}(r=-0.41)$ and a negative slope $(-0.0035 \pm 0.0030)$.

If we assume that, on average, $\mathrm{CH}_{2} \mathrm{O}$ from other (nonvehicle) sources transported to Moody Tower is uncorrelated with the morning $\mathrm{CO}$ traffic peak, then the linear regression slopes derived for the morning traffic peaks averaged over a large number of days should provide a measure of the $\mathrm{CH}_{2} \mathrm{O}$ to $\mathrm{CO}$ emission ratio for on-road vehicles alone. The weighted average (i.e. each day's slope weighted by the inverse of the square of its confidence limit, Bevington, 1969) of the regression slopes for all 13 days is $0.30 \pm 0.02 \%$, which is in excellent agreement with the result above for 18 September and the estimate of Cowling et al. (2007).

A recent tunnel study (Ban-Weiss et al., 2008) suggests significantly lower $\mathrm{CH}_{2} \mathrm{O}$ to $\mathrm{CO}$ emission ratio for on-road vehicles. Using 2006 measurements made in a San Francisco Bay Area highway tunnel, these workers derive molar ratios of $0.062 \%$ and $0.149 \%$ for light duty, gasoline fueled vehicles and medium duty/heavy duty diesel fueled trucks, respectively. Both of these results are significantly lower than the result from the 2006 ambient measurements presented here. The reason for the differences between the two studies is not well established, but it may reflect the specific driving conditions, the vehicle mix and the relative absence of cold starts in the tunnel. However, the tunnel study does suggest that the result from the present work likely overesti-
Table 2. Slopes derived from linear regressions of $\mathrm{CH}_{2} \mathrm{O}$ vs. $\mathrm{CO}$ for the selected morning vehicle traffic peak periods during 2006. Data were collected at the Moody Tower site.

\begin{tabular}{lccc}
\hline Date & Local Time & Slope \pm C.L. ${ }^{*}$ & $r^{2}$ \\
\hline 20 August & $04: 20-07: 20$ & $0.0073 \pm 0.0027$ & 0.68 \\
21 August & $04: 20-06: 50$ & $0.0017 \pm 0.0005$ & 0.77 \\
23 August & $03: 30-07: 40$ & $0.0063 \pm 0.0010$ & 0.87 \\
24 August & $05: 00-07: 00$ & $0.0020 \pm 0.0027$ & 0.21 \\
2 September & $04: 10-07: 10$ & $0.0055 \pm 0.0014$ & 0.83 \\
6 September & $03: 00-07: 40$ & $0.0025 \pm 0.0007$ & 0.68 \\
7 September & $03: 50-06: 50$ & $0.0048 \pm 0.0022$ & 0.57 \\
15 September & $05: 50-08: 20$ & $0.0066 \pm 0.0017$ & 0.85 \\
18 September & $04: 10-08: 10$ & $0.0026 \pm 0.0003$ & 0.92 \\
20 September & $02: 10-07: 10$ & $-0.0035 \pm 0.0030$ & 0.17 \\
26 September & $04: 40-07: 30$ & $0.0053 \pm 0.0009$ & 0.92 \\
27 September & $04: 20-07: 50$ & $0.0033 \pm 0.0017$ & 0.48 \\
28 September & $06: 00-08: 20$ & $0.0036 \pm 0.0015$ & 0.71 \\
\hline Average & & $0.0030 \pm 0.0002$ & \\
\hline
\end{tabular}

${ }^{*}$ C.L. $=95 \%$ confidence limit of the slope.

mates rather than underestimates the $\mathrm{CH}_{2} \mathrm{O}$ to $\mathrm{CO}$ emission ratio for on-road vehicles in $\mathrm{HGB}$.

\subsection{Quantification of formaldehyde formed from oxidation of on-road VOC emissions}

Following a procedure similar to that of Sect. 3.1, the total amount of secondary $\mathrm{CH}_{2} \mathrm{O}$ that can form within $\mathrm{HGB}$ from on-road vehicle emissions can be estimated from the product of the total ethene and propene emissions from vehicles times the product yield of $\mathrm{CH}_{2} \mathrm{O}$ from these alkenes. Rather than relying upon emission inventories to provide total ethene and propene emissions, we use the measured alkene to $\mathrm{CO}$ emission ratios multiplied by total $\mathrm{CO}$ emissions. This latter quantity will be taken from emission inventories, since this aspect of inventories has been more extensively tested. The primary $\mathrm{CH}_{2} \mathrm{O}$ emission flux determined in the preceding section is also based upon the total $\mathrm{CO}$ emissions, so any uncertainty in this quantity will not affect the determination of the relative amount of primary versus secondary $\mathrm{CH}_{2} \mathrm{O}$ associated with vehicle emissions. In this section, we again neglect any unreacted ethene or propene and $\mathrm{CH}_{2} \mathrm{O}$ produced from oxidation of alkane, aromatics, and heavier alkenes.

Warneke et al. (2007) have derived the emission ratios of ethene and propene to $\mathrm{CO}$ characteristic of urban emissions using ambient measurements near the US east coast. They find good agreement with the results of Baker et al. (2008), who analyzed measurements from 28 US cities. Both of these studies generally quantified the ratios from on-road vehicle emissions, since that is the primary source of alkenes and $\mathrm{CO}$ in most of these cities. Since the vehicle fleet and the hydrocarbon gasoline composition does not vary markedly among different regions of the US, the Warneke et al. (2009) 


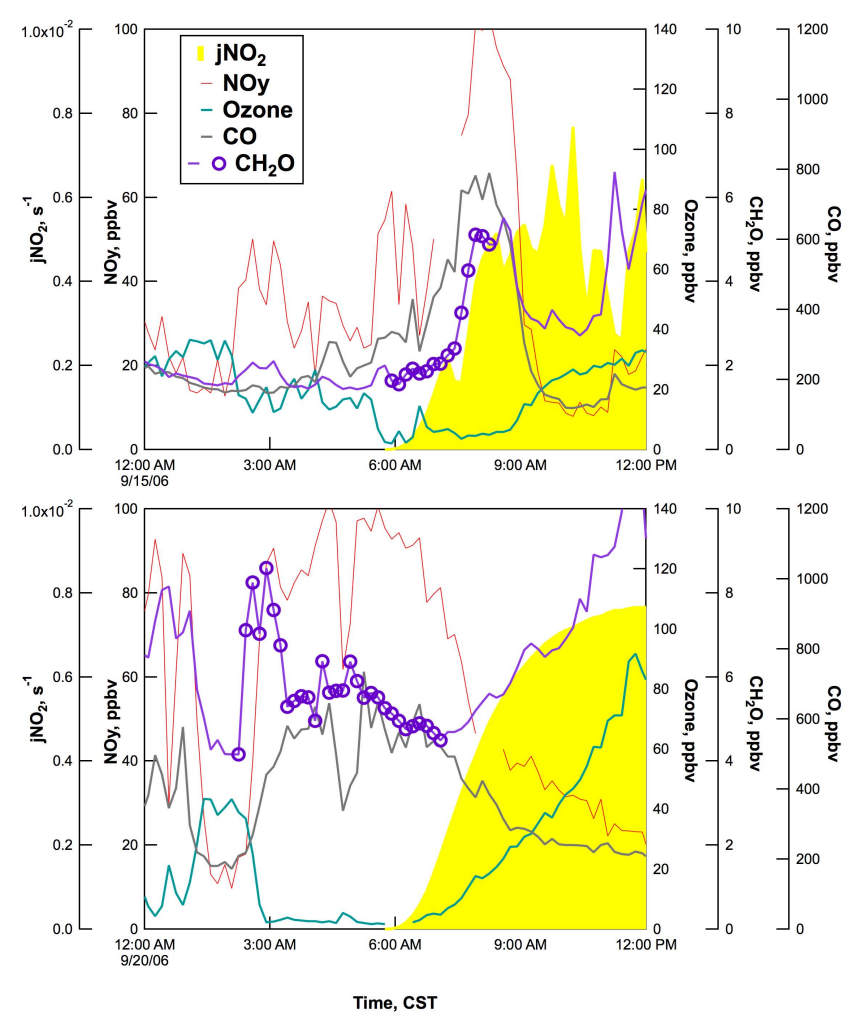

Fig. 6. Time series observed during the mornings of 15 and 20 September 2006 at Moody Tower in the same format as Fig. 5. Small circles indicate the $\mathrm{CH}_{2} \mathrm{O}$ data for those days included in the linear regressions illustrated in Fig. 4.

results are taken to be representative of the HGB vehicle fleet. Table 3 gives these alkene to $\mathrm{CO}$ ratios, as well as the secondary $\mathrm{CH}_{2} \mathrm{O}$ to $\mathrm{CO}$ ratio implied by these ratios combined with the product yields of $\mathrm{CH}_{2} \mathrm{O}$ from these alkenes (Seinfeld and Pandis, 1998) discussed earlier.

Table 3 includes the integration of the on-road vehicle emissions of $\mathrm{CO}$, ethene, propene and $\mathrm{CH}_{2} \mathrm{O}$ in the $\mathrm{HGB}$ region, which is defined here as latitude 28.9 to $30.6^{\circ} \mathrm{N}$ and longitude 94.4 to $96.2^{\circ} \mathrm{W}$. The integration is performed on the NEI 2005 inventory provided by EPA. However, CO emissions in the NEI 2005 inventory, which is based upon the MOBILE6 emission model, exceeds measured CO concentrations by about a factor of 2 (Parrish, 2006; Brioude et al., 2011). Consequently, to obtain an accurate estimate we reduce the integrated $\mathrm{CO}$ emission estimate by half. The alkene and $\mathrm{CH}_{2} \mathrm{O}$ to $\mathrm{CO}$ emission ratios then allow total emissions of the alkenes and $\mathrm{CH}_{2} \mathrm{O}$ to be derived, which are included in Table 3 in the row labeled "best estimate". For all species except $\mathrm{CO}$ these "best estimate" emissions are in good agreement $( \pm 25 \%)$ with the integrated NEI 2005 emissions.

Here again, the estimate of the secondary $\mathrm{CH}_{2} \mathrm{O}$ may be an overestimate, since some of the ethene and propene may be transported out of the HGB region before reacting to form $\mathrm{CH}_{2} \mathrm{O}$, but may be an underestimate as $\mathrm{CH}_{2} \mathrm{O}$ produced from oxidation of alkane, aromatics, and heavier alkenes is not included. The emission ratio of the alkenes to $\mathrm{CO}$ are estimated as accurate to $\pm 30 \%$ (Warneke et al., 2009), which are taken as the uncertainties for the primary emissions of the alkenes, while the estimate for the uncertainty of the secondary $\mathrm{CH}_{2} \mathrm{O}$ formation rate is taken as $\pm 40 \%$ for reasons similar to the arguments given in Sect. 3.1.

Table 3 summarizes the estimated primary $\mathrm{CH}_{2} \mathrm{O}$ emitted and secondary $\mathrm{CH}_{2} \mathrm{O}$ formed from the on-road vehicle fleet. The primary emission estimate is based upon the ambient $\mathrm{CH}_{2} \mathrm{O}$ to $\mathrm{CO}$ ratio measured during the morning traffic peak, and hence is an upper limit. These results indicate that no more than $28 \pm 8 \%$ of the $\mathrm{CH}_{2} \mathrm{O}$ from the on-road vehicle fleet in HGB is of primary origin, with the remainder, at least $72 \pm 8 \%$, of secondary origin, produced from oxidation of alkenes also emitted by the on-road vehicles. This estimated apportionment is expected to approximately apply to all US urban areas.

\section{Comparison to other analyses}

Based upon the 2000-2009 measurements and the 2005 emission inventory considered here, we have found that secondary production from alkenes emitted by petrochemical facilities and the on-road vehicle fleet is the major source of $\mathrm{CH}_{2} \mathrm{O}$ (95 $\pm 3 \%$ of total) in HGB (see Table 4 for summary). Primary emissions from these sources make a much smaller contribution $(5 \pm 3 \%)$. Three previous studies addressed these same issues using correlations of ambient $\mathrm{CH}_{2} \mathrm{O}$ concentrations with concentrations of pollutants that are recognized as predominantly from either primary emissions $\left(\mathrm{CO}, \mathrm{SO}_{2}\right)$ or secondary formation processes $\left(\mathrm{O}_{3}\right.$, PAN). All three of these studies concluded that primary emissions make much larger contributions: $37 \%$ (Friedfeld et al., 2002), $40 \%$ (Buzcu Guven and Olaguer, 2011) (with $36 \%$ from secondary sources and an additional $24 \%$ biogenic contribution), and $47 \%$ (Rappenglück et al., 2010) (with only $24 \%$ from secondary sources and the remaining $29 \%$ unattributed). These contrasting findings are attributed to two important problems that led the correlation-based approaches to inaccurate results; these same problems may affect many correlation-based source apportionment analyses of secondary pollutants.

The first problem is that the correlation-based studies explicitly or implicitly addressed source contributions to measured ambient $\mathrm{CH}_{2} \mathrm{O}$ concentrations at particular sites, while the present analysis addresses the total mass of $\mathrm{CH}_{2} \mathrm{O}$ emitted and formed within the entire HGB region. It is the emission fluxes and production rates (expressed as mass or moles per unit time) that quantify the amount of $\mathrm{CH}_{2} \mathrm{O}$ emitted or produced within $\mathrm{HGB}$, and it is these quantities that determine the importance of $\mathrm{CH}_{2} \mathrm{O}$ to the photochemical production of $\mathrm{O}_{3}$ within HGB. It is critical to note that measured ambient concentrations at any particular location are 
Table 3. Summary of emission fluxes of CO, ethene, propene and formaldehyde estimated for the HGB on-road vehicle fleet, given as 24-h averages. The indicated uncertainties are estimated $95 \%$ confidence limits.

\begin{tabular}{llllll}
\hline & Primary CO & Primary Ethene & Primary Propene & Secondary $\mathrm{CH}_{2} \mathrm{O}$ & Primary $\mathrm{CH}_{2} \mathrm{O}$ \\
\hline $\mathrm{X}_{i} / \mathrm{CO}^{1}$ & - & $4.6 \pm 1.4^{2}$ & $1.4 \pm 0.4^{2}$ & $7.7 \pm 2.3^{3}$ & $3.0 \pm 0.2^{4}$ \\
${\mathrm{HGB} \mathrm{NEI} 2005^{5}}^{\mathrm{HGB} \text { best estimate }}$ & 1684 & 4.0 & 1.1 & - & 2.0 \\
& $842^{7}$ & $3.8 \pm 1.2^{8}$ & $1.15 \pm 0.34^{8}$ & $6.5 \pm 2.6^{8}$ & $2.5^{8,9}$ \\
\hline
\end{tabular}

${ }^{1}$ Units: $10^{-3}$ mole mole $^{-1} \mathrm{CO}$.

2 Emission ratio of alkene to $\mathrm{CO}$ derived from ambient measurements (Warneke et al., 2007).

${ }^{3}$ Estimated from the sum of two terms, one for ethene and one for propene; each term is the product of the emission ratio of the alkene to $\mathrm{CO}$, and the $\mathrm{CH}_{2} \mathrm{O}$ yields of the respective alkene.

${ }^{4}$ Emission ratio of $\mathrm{CH}_{2} \mathrm{O}$ to $\mathrm{CO}$ from ambient measurements at Moody Tower in 2006 - see discussion in text.

5 NEI 2005 inventory integrated over HGB. Units: $\mathrm{kmole}^{-1}$ on average summer weekday.

${ }^{6}$ Units: kmole $\mathrm{h}^{-1}$ on average summer weekday.

7 Taken as $50 \%$ of NEI 2005 integration - see discussion in text.

${ }^{8}$ Product of $\mathrm{X}_{i} / \mathrm{CO}$ and primary $\mathrm{CO}$ emissions.

${ }^{9}$ As discussed in the text, this is an upper limit; no confidence limit is indicated.

Table 4. Summary of the rates of secondary production and primary emission of $\mathrm{CH}_{2} \mathrm{O}$ in HGB given as 24-h averages with estimated $1-\sigma$ confidence limits. The percentages in parentheses indicate relative contributions to the total (primary + secondary) rate. Units of absolute rates are $\mathrm{kmol} \mathrm{h}^{-1}$ and uncertainties of primary emissions are estimated as $\pm 30 \%$.

\begin{tabular}{lrr}
\hline Source & Secondary & Primary \\
\hline Point sources & $220 \pm 90(92 \%)$ & $10.6(4 \%)$ \\
On-road vehicles & $6.5 \pm 2.6(3 \%)$ & $2.5(1 \%)$ \\
Total & $227 \pm 90$ & 13.1 \\
Percent total & $95 \pm 3 \%$ & $5 \pm 3 \%$ \\
\hline
\end{tabular}

affected not only by emission fluxes and production rates, but also by transport (including dilution) processes and loss rates. The relative contributions to measured ambient concentrations are directly related to the relative emission fluxes and production rates only if the loss rates and the effects of transport and dilution are identical for each of the sources. In the case of $\mathrm{CH}_{2} \mathrm{O}$, this direct relationship does not apply, because secondary sources are at a maximum rate during the daytime when dilution and photochemical loss rates are also at a maximum.

The diurnal cycle of $\mathrm{CH}_{2} \mathrm{O}$ in HGB provides an example of the potentially confounding effects of dilution and loss rates. Observed surface concentrations of $\mathrm{CH}_{2} \mathrm{O}$ (Fig. 7a) exhibit a relatively modest daytime maximum, but those daytime concentrations are present throughout a deep mixed convective boundary layer (CBL). Nighttime concentrations average only a factor of 2 lower than the daytime maxima, but represent a much shallower mixed layer. After normalizing those observed concentrations for mixing height (Fig. 7b), the average daytime maximum is more than a factor of 10 higher than the average nighttime concentrations. In addition to the greater dilution of formaldehyde during the day, the lifetime of $\mathrm{CH}_{2} \mathrm{O}$ ( 3 to $4 \mathrm{~h}$ in full sun, Seinfeld and Pandis, 1998) is relatively short during the day, but much longer at night. Thus, $\mathrm{CH}_{2} \mathrm{O}$ from any particular source would accumulate to higher concentrations at night than during the day, even if the emission rates and dilution effects remained constant.

The preceding discussion indicates that $\mathrm{CH}_{2} \mathrm{O}$ from different sources is expected to experience a wide spectrum of loss rates and transport effects depending upon the diurnal dependence of the source strength. Hence, any analysis that aims to determine the relative importance of different sources must account for these confounding effects. In the present work, careful attention is given to ensure comparison between sources on the basis of total mass of formaldehyde emitted or produced, not directly on observed concentrations. Figure 1 of Buzcu Guven and Olaguer (2011) shows that the source factors derived from correlation analyses can have very strong diurnal variation. Such analyses based solely upon concentrations without accounting for varying transport and loss rates are expected to err substantially.

A second major problem with the three earlier studies is that they are based on multivariate correlation approaches, and interpretation of the results required assumptions regarding the cause of the correlations; however, the hypothesized causes are incorrect in important respects. First, all three studies take $\mathrm{CO}$ and two of the studies (Rappenglück et al., 2010; Buzcu Guven and Olaguer, 2011) take $\mathrm{SO}_{2}$ as markers for primary emissions of $\mathrm{CH}_{2} \mathrm{O}$. They also assume that $\mathrm{O}_{3}$ (Friedfeld et al., 2002) or PAN (Rappenglück et al., 2010; Buzcu Guven and Olaguer, 2011) is a reliable marker for secondary production of $\mathrm{CH}_{2} \mathrm{O}$. They then further assume that any correlation of $\mathrm{CH}_{2} \mathrm{O}$ with $\mathrm{CO}$ or $\mathrm{SO}_{2}$ indicates primary emission, and that only correlation of $\mathrm{CH}_{2} \mathrm{O}$ with $\mathrm{O}_{3}$ or PAN can indicate secondary production. However, none of the studies presents analysis to support these assumptions; in effect they assume that correlation proves cause. They neglect to consider that ambient $\mathrm{CH}_{2} \mathrm{O}$ concentrations may well correlate with ambient concentrations of $\mathrm{CO}$ from mobile source emissions and $\mathrm{SO}_{2}$ from industrial emissions because those 

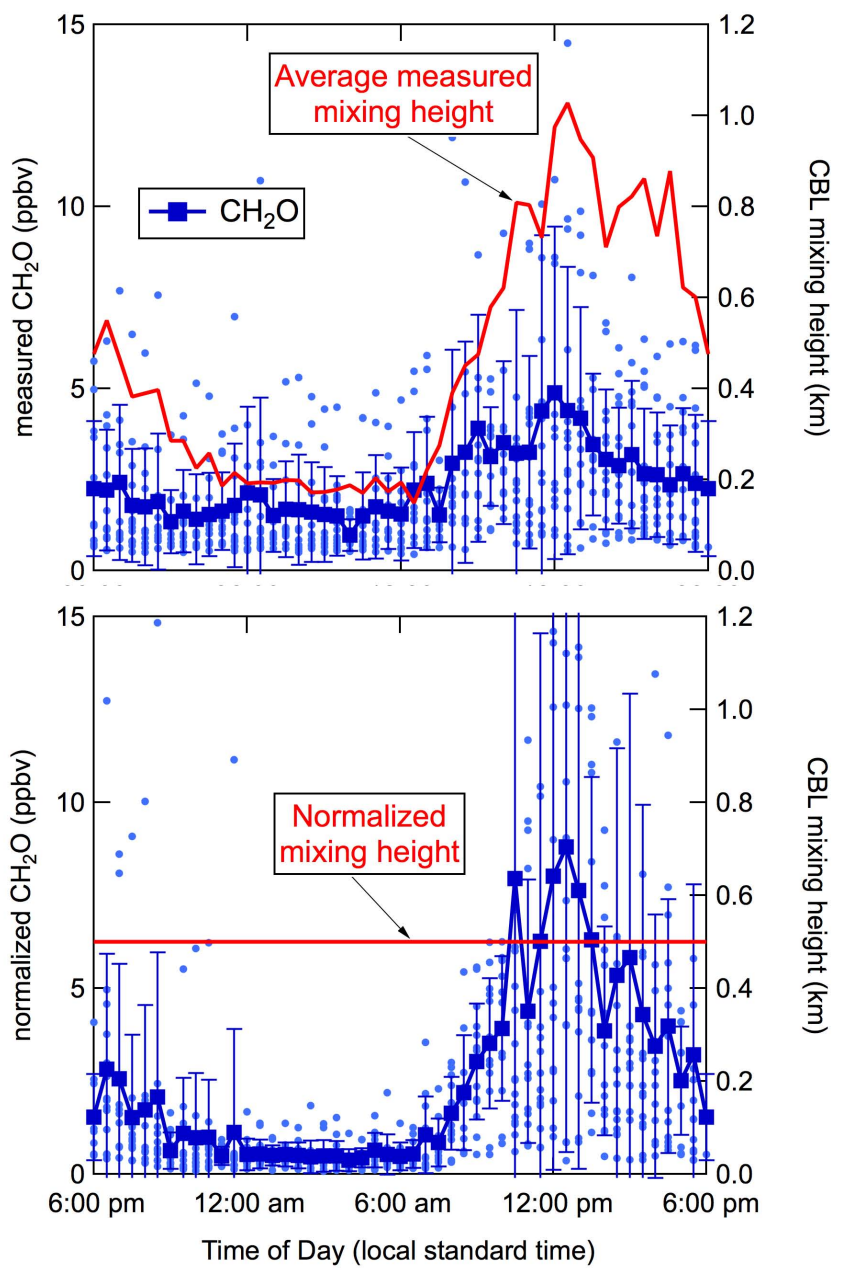

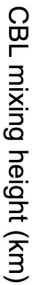

Fig. 7. $\mathrm{CH}_{2} \mathrm{O}$ concentrations and mixing heights measured aboard the NOAA research vessel Ronald H. Brown during TexAQS 2006 within the HGB area. (a) The light blue points include all 30-min averages recorded during the study, and the dark blue symbols indicate averages and standard deviations for 30 min diurnal periods. The red line indicates average mixing height (i.e. CBL depth) (b) The calculated $\mathrm{CH}_{2} \mathrm{O}$ concentrations expected if the integrated column concentration in (a) were uniformly mixed to a constant mixing height of $500 \mathrm{~m}$ (after Gilman et al., 2009).

same sources also emit large quantities of reactive VOCs that form secondary formaldehyde. None of the three studies presents any evidence regarding the actual source of the formaldehyde that correlates with the primary emission tracers.

The TexAQS 2000 aircraft data discussed above in Sect. 3 (Figs. 1-3) can illuminate the dominant cause of the correlation of $\mathrm{CH}_{2} \mathrm{O}$ with $\mathrm{SO}_{2}$. The 27 and 28 August flights sampled the plume from HSC under similar meteorological conditions. Figure 8 shows the $\mathrm{CH}_{2} \mathrm{O}$ vs. $\mathrm{SO}_{2}$ correlation for those two flights with the measurements divided into relatively fresh emissions (grey points) and the more aged plume (red points). The fresh emissions have a weak corre-

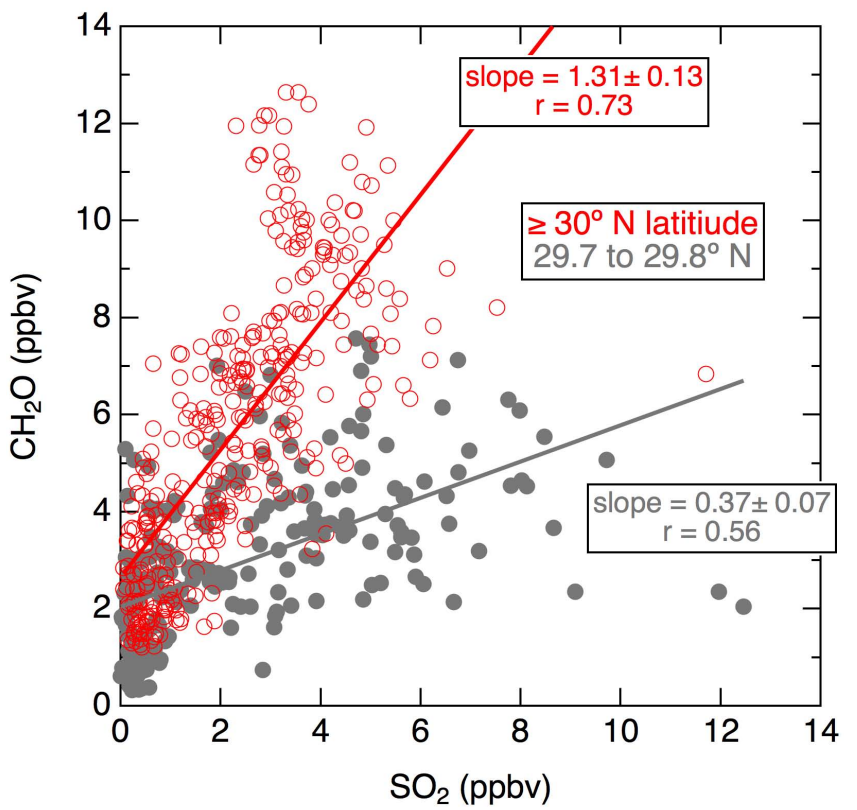

Fig. 8. Relationships between $\mathrm{CH}_{2} \mathrm{O}$ and $\mathrm{SO}_{2}$ measured by the Electra on 27 and 28 August 2000 within the plume from HSC (taken as east of $-95.5^{\circ}$ longitude to avoid plume from Parish power plant that moves over the western part of the city). The track for the first flight is shown in Fig. 1, and the second flight track was similar. Data are color-coded according to whether they were collected directly over HSC and immediately downwind (grey points, $29.7-29.8^{\circ} \mathrm{N}$ ) or further downwind (red points, 30.0-30.3 $\mathrm{N}$ ). The lines and annotations of the respective colors indicate the linear regressions to the data sets.

lation, a small $\mathrm{CH}_{2} \mathrm{O}$ to $\mathrm{SO}_{2}$ ratio and small $\mathrm{CH}_{2} \mathrm{O}$ concentrations compared to more aged emissions sampled further downwind. The stronger correlation of $\mathrm{CH}_{2} \mathrm{O}$ with $\mathrm{SO}_{2}$ and increasing $\mathrm{CH}_{2} \mathrm{O}$ concentrations that appear during transport is the signature of secondary formation of $\mathrm{CH}_{2} \mathrm{O}$ in a plume initially rich in $\mathrm{SO}_{2}$. The correlation grows into the plume through photochemical processing during plume transport. Co-located primary emissions of $\mathrm{CH}_{2} \mathrm{O}$ and $\mathrm{SO}_{2}$ would have the strongest correlation and highest concentrations of both species closest to the source. Hence, correlation of $\mathrm{CH}_{2} \mathrm{O}$ with $\mathrm{SO}_{2}$ without a detailed analysis of the cause of the correlation cannot be taken as indicative of primary emissions of $\mathrm{CH}_{2} \mathrm{O}$.

Stutz et al. (2011) utilized a mobile laboratory during the 2009 field study to investigate $\mathrm{CH}_{2} \mathrm{O}$ plumes downwind from industrial facilities. They investigated the spatial extent of the plumes and evaluated them in the context of the prevailing wind to identify the sources of observed plumes. A single primary $\mathrm{CH}_{2} \mathrm{O}$ source was identified, which was in the Texas City area with an emission rate of $\sim 25 \mathrm{~kg} \mathrm{~h}^{-1}$, corresponding to the total Texas City primary $\mathrm{CH}_{2} \mathrm{O}$ emissions measured by Mellqvist et al. (2010b) (Table 1). In this plume the $\mathrm{CH}_{2} \mathrm{O} / \mathrm{SO}_{2}$ ratio was $0.07-0.12$, much smaller than the 
0.4-1.3 ratio found downwind of the HSC (Fig. 8), which again indicates that the $\mathrm{CH}_{2} \mathrm{O}$ downwind of $\mathrm{HSC}$ is of secondary origin.

Similar considerations apply to correlations of $\mathrm{CH}_{2} \mathrm{O}$ with $\mathrm{CO}$. Vehicle emissions of $\mathrm{CO}$ and VOCs, including alkenes, accumulate together in urban air masses. Photochemical processing produces $\mathrm{CH}_{2} \mathrm{O}$, which leads to significant correlations of ambient concentrations of $\mathrm{CH}_{2} \mathrm{O}$ and $\mathrm{CO}$. Figure 9 illustrates the development of this correlation observed in the 27 and 28 August flights. As the air moves downwind, increased concentrations of both $\mathrm{CO}$ (from accumulation of emissions) and $\mathrm{CH}_{2} \mathrm{O}$ (from accumulation of photochemical production) are observed. There is significant correlation of $\mathrm{CH}_{2} \mathrm{O}$ with $\mathrm{CO}(r=0.76$ for all data in Fig. 9), with higher correlations and different slopes observed downwind of HSC $(r=0.87$, red to orange points in Fig. 9) and downwind of the central urban area $(r=0.83$, green to purple points in Fig. 9). Importantly, nearly all of the observed $\mathrm{CH}_{2} \mathrm{O}$ is due to secondary production, as the ratio of $\mathrm{CH}_{2} \mathrm{O}$ to $\mathrm{CO}$ in primary emissions from vehicles (black dotted line in Fig. 9; see Sect. 4.1) is a factor of 15 to 30 smaller than the observed $\mathrm{CH}_{2} \mathrm{O}$ vs. $\mathrm{CO}$ slopes. In summary, it is incorrect to assume that correlations of $\mathrm{CH}_{2} \mathrm{O}$ with either $\mathrm{SO}_{2}$ or $\mathrm{CO}$ necessarily indicate primary emissions of $\mathrm{CH}_{2} \mathrm{O}$.

Similarly, neither $\mathrm{O}_{3}$ nor PAN can necessarily be taken as a tracer for secondary $\mathrm{CH}_{2} \mathrm{O}$ formation without firm analysis to justify that assumption. Further, the correlation coefficient and slope between these species and $\mathrm{CH}_{2} \mathrm{O}$ vary significantly depending upon the precursor mix and degree of processing. The formation of both $\mathrm{O}_{3}$ and PAN requires both VOCs and $\mathrm{NO}_{\mathrm{x}}$ to be present. The photochemical processing of an emitted plume with large amounts of reactive VOCs without $\mathrm{NO}_{\mathrm{x}}$ would be expected to form copious amounts of secondary $\mathrm{CH}_{2} \mathrm{O}$, but little or no $\mathrm{O}_{3}$ or PAN. Alternatively, the photochemical processing of a plume with large primary emissions of both $\mathrm{CH}_{2} \mathrm{O}$ and $\mathrm{NO}_{\mathrm{x}}$ would be expected to form large amounts of $\mathrm{O}_{3}$, but any remaining unreacted $\mathrm{CH}_{2} \mathrm{O}$ that correlated with that $\mathrm{O}_{3}$ would be considered secondary. Figure 2 shows an example of the variability of the $\mathrm{CH}_{2} \mathrm{O}$ correlation with $\mathrm{O}_{3}$ within the HSC plume (east of $-95.5^{\circ}$ longitude). Downwind of the Houston central urban area (west of $-95.5^{\circ}$ longitude), the $\mathrm{CH}_{2} \mathrm{O}$ correlation with $\mathrm{O}_{3}$ is significant $(r=0.72)$ but with a much smaller slope ( 0.07 ppbv $\mathrm{CH}_{2} \mathrm{O} / \mathrm{ppbv} \mathrm{O}_{3}$ ) than observed downwind in the HSC plume (as large as 0.15 ppbv $\mathrm{CH}_{2} \mathrm{O} / \mathrm{ppbv} \mathrm{O}_{3}$ ). The coincident $\mathrm{CH}_{2} \mathrm{O}$ and PAN data from the 27 and 28 August flights are much more limited, but variability in correlation coefficient and slope between these two species is also apparent. For example, downwind of the Houston central urban area, the $\mathrm{CH}_{2} \mathrm{O}$ vs. PAN correlation coefficient is 0.91 with a slope of $2.7 \mathrm{ppbv} \mathrm{CH}_{2} \mathrm{O} / \mathrm{ppbv} \mathrm{PAN}$; the corresponding values downwind of $\mathrm{HSC}$ are 0.77 with a slope of $4.4 \mathrm{ppbv}$ $\mathrm{CH}_{2} \mathrm{O} /$ ppbv PAN.

In summary, the correlations between ambient concentrations $\mathrm{CH}_{2} \mathrm{O}$ and those of primary pollutants (e.g. $\mathrm{SO}_{2}$ and

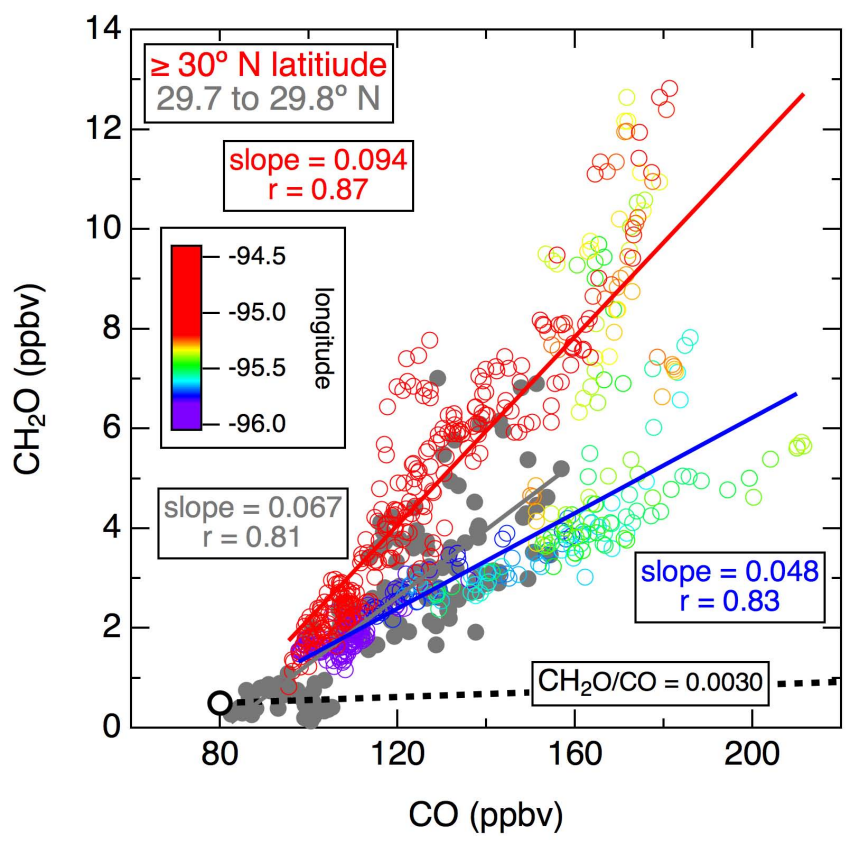

Fig. 9. Relationships between $\mathrm{CH}_{2} \mathrm{O}$ and $\mathrm{CO}$ measured by the Electra on 27 and 28 August 2000 in the same format as Fig. 8. The track for the first flight is shown in Fig. 1, and the second flight track was similar. Data from within the entire plume downwind from the Houston area are included. Data are color-coding according latitude range (grey points, $29.7-29.8^{\circ} \mathrm{N}$; colored points, $30.0-30.3^{\circ} \mathrm{N}$ ) and longitude according to color-scale in plot. The lines and annotations of the respective colors indicate the linear regressions to the data sets divided by latitude range and longitude (red east and blue west of $-95.4^{\circ}$ longitude). The dotted black line indicates the expected mixing ratio enhancements from primary emissions of $\mathrm{CH}_{2} \mathrm{O}$ and $\mathrm{CO}$ from the on-road vehicle fleet with a ratio of $0.3 \%$.

$\mathrm{CO}$ ) and other secondary products (e.g. $\mathrm{O}_{3}$ and PAN) arise from complex atmospheric interactions, vary substantially depending upon the mix of precursors in and air mass, and are strongly affected by transport and loss processes. Consequently, source apportionment analyses based solely on correlations cannot be expected to be reliable. The problems with such approaches are expected to be particularly severe when attempting source apportionment analyses of secondary species such as $\mathrm{CH}_{2} \mathrm{O}$, since such a large number of processes are involved in determining the correlations between the atmospheric concentrations of various secondary and primary species.

\section{Discussion and conclusions}

We have evaluated the rates of secondary production and primary emission of $\mathrm{CH}_{2} \mathrm{O}$ from petrochemical industrial facilities and on-road vehicles in Houston Texas region based upon ambient measurements made in the 2000-2009 period and a measurement constrained emission inventory based 
upon the EPA NEI 2005. This evaluation (summarized in Table 4) shows that by far the predominant source of $\mathrm{CH}_{2} \mathrm{O}$ ( $92 \pm 4 \%$ of total) is secondary production formed during the atmospheric oxidation of the alkenes emitted from the petrochemical facilities that characterize the industrial activity in HGB. These same facilities also emit much smaller amounts of primary $\mathrm{CH}_{2} \mathrm{O}(4 \pm 2 \%$ of total); these primary emissions (in contrast to the alkene emissions) are well predicted by current emission inventories. $\mathrm{CH}_{2} \mathrm{O}$ from the onroad vehicle fleet $(4 \pm 2 \%$ of total) is also dominated by the secondary $\mathrm{CH}_{2} \mathrm{O}$ formed from the alkenes directly emitted by the vehicles. We quantified an upper limit for the amount of primary $\mathrm{CH}_{2} \mathrm{O}$ emitted by this fleet; that amount is relatively small ( $28 \pm 8 \%$ of the vehicle total), and is well predicted by current emission inventories.

This evaluation indicates that there is no strong observational evidence for large primary $\mathrm{CH}_{2} \mathrm{O}$ emissions beyond those presently included in emission inventories. There is also no need to hypothesize such emissions for models to adequately reproduce observed $\mathrm{CH}_{2} \mathrm{O}$ or $\mathrm{O}_{3}$ concentrations within HGB. Several studies (Wert et al., 2003; Jiang and Fast, 2004; Byun et al., 2007; Kim et al., 2011) have shown reasonable agreement with observations when the ethene and propene emissions are increased according to the results of measured emissions from the petrochemical facilities.

Since $\mathrm{CH}_{2} \mathrm{O}$ is dominated by secondary production, there is no large fraction of $\mathrm{CH}_{2} \mathrm{O}$ sources in HGB that can respond to direct, emission control efforts focused on primary $\mathrm{CH}_{2} \mathrm{O}$ emissions, although the Texas City source (Stutz et al., 2011) discussed above could be controlled by a focused effort. Ongoing efforts to control HRVOC emissions from the petrochemical facilities and VOC emission controls on the motor vehicle fleet will effectively control secondary $\mathrm{CH}_{2} \mathrm{O}$ formation in HGB.

We find no evidence that sporadic episodes of primary $\mathrm{CH}_{2} \mathrm{O}$ emissions from the petrochemical industrial facilities make a significant contribution to $\mathrm{CH}_{2} \mathrm{O}$ in $\mathrm{HGB}$. Although we do not quantify other possible sources of primary emissions, such as off-road mobile sources, these are not expected to constitute major $\mathrm{CH}_{2} \mathrm{O}$ emission sources in HGB. Secondary formation of $\mathrm{CH}_{2} \mathrm{O}$ from biogenic VOCs, especially isoprene, has not been addressed, and air coming into the Houston area from forested regions to the north and east may contain a significant amount of secondary formaldehyde formed from isoprene. This biogenic secondary $\mathrm{CH}_{2} \mathrm{O}$ could play a role in initiating the photochemical processing of the ozone precursors emitted in Houston.

The correlation-based analyses of Friedfeld et al. (2002), Rappenglück et al. (2010) and Buzcu Guven and Olaguer (2011) reached conclusions in conflict with those presented here. However, those studies are flawed because (1) they analyze ambient concentrations, not the total quantity of $\mathrm{CH}_{2} \mathrm{O}$ emitted or formed and do not account for differential dilution and loss processes between sources, and (2) they rely only on correlations without firmly establishing the causes of the cor- relations. Analyses presented here indicate that the assumed causes were in fact incorrect. Similar problems must be suspected in any correlation-based analyses of $\mathrm{CH}_{2} \mathrm{O}$ sources conducted in other urban areas (e.g. Li et al., 1997; Garcia et al., 2006). Indeed, all correlation-based source apportionment analyses of secondary species must be investigated for similar problems before their conclusions can be confidently accepted.

\section{Supplementary material related to this article is available online at: http://www.atmos-chem-phys.net/12/ 3273/2012/acp-12-3273-2012-supplement.pdf.}

Acknowledgements. This work was funded in part by NOAA's Air Quality and Atmospheric Chemistry and Climate Programs and in part by the Texas Commission on Environmental Quality (TCEQ). The authors are grateful to the Principal Investigators of the Moody Tower site and the Baylor Aztec aircraft for making their data sets available.

Edited by: A. Hofzumahaus

\section{References}

Anderson, L. G., Lanning, J. A., Barrell, R., Miyagishima, J., Jones, R. H., and Wolfe, P.: Sources and sinks of formaldehyde and acetaldehyde: An analysis of Denver's ambient concentration data, Atmos. Environ., 3, 2113-2123, 1996.

Baker, A. K., Beyersdorf, A. J., Doezema, L. A., Katzenstein, A., Meinardi, S., Simpson, I. J., Blake, D. R., and Rowland, F. S.: Measurements of nonmethane hydrocarbons in 28 United States cities, Atmos. Environ., 42, 170-182, doi:10.1016/j.atmosenv.2007.09.007, 2008.

Ban-Weiss, G. A., McLaughlin, J. P., Harley, R. A., Kean, A. J., Grosjean, E., and Grosjean, D.: Carbonyl and nitrogen dioxide emissions from gasoline- and diesel-powered motor vehicles, Environ. Sci. Technol., 42, 3944-3950, 2008.

Baylor University: Analysis of airborne data collected during 2006 to characterize $\mathrm{HCHO}$ emissions and sources in the Houston area, Final Report Project H-103B, Texas Environmental Research Consortium: Houston, TX, 2009.

Bevington, P. R.: Data reduction error analysis for the physical sciences, McGraw-Hill Book Company, New York, 1969.

Brioude, J., Kim, S.-W., Angevine, W. M., Frost, G. J., Lee, S.-H., McKeen, S. A., Trainer, M., Fehsenfeld, F. C., Holloway, J. S., Ryerson, T. B., Williams, E. J., Petron, G., and Fast, J. D.: Top-down estimate of anthropogenic emission inventories and their interannual variability in Houston using a mesoscale inverse modeling technique, J. Geophys. Res., D20305, doi:10.1029/2011JD016215, 2011.

Brown, S. S., Dube, W. P., Fuchs, H., Ryerson, T. B., Wollny, A. G., Brock, C. A., Bahreini, R., Middlebrook, A. M., Neuman, J. A., Atlas, E., Roberts, J. M., Osthoff, H. D., Trainer, M., Fehsenfeld, F. C., and Ravishankara, A. R.: Reactive uptake coefficients for $\mathrm{N}_{2} \mathrm{O}_{5}$ determined from aircraft measurements during the Second Texas Air Quality Study: Comparison to cur- 
rent model parameterizations, J. Geophys. Res., 114, D00F10, doi:10.1029/2008JD011679, 2009.

Brown, S. S., Dubé, W. P., Peischl, J., Ryerson, T. B., Atlas, E., Warneke, C., de Gouw, J., Te Lintel Hekkert, S., Brock, C. A., Flocke, F., Trainer, M., Parrish, D. D., Fehsenfeld, F. C., and Ravishankara, A. R.: Budgets for nocturnal VOC oxidation by nitrate radicals aloft during the 2006 Texas Air Quality Study, J. Geophys. Res., 116, D24305, doi:10.1029/2011JD016544, 2011.

Buzcu Guven, B. and Olaguer, E. P.: Ambient formaldehyde source attribution in Houston during TexAQS II and TRAMP, Atmos. Environ., 45, 4272-4280, 2011.

Byun, D. W., Kim, S.-T., and Kim, S.-B.: Evaluation of air quality models for the simulation of a high ozone episode in the Houston metropolitan area, Atmos. Environ., 41, 837-853, doi:10.1016/j.atmosenv.2006.08.038, 2007.

Cowling, E. B., Furiness, C., Dimitriades, B., and Parrish, D.: Final rapid synthesis report: Findings from the second Texas Air Quality Study (TexAQS II), Final Report, TCEQ Contract No. 5824 65614, Texas Commission on Environmental Quality, Austin, Texas, 143 pp., 2007.

Daube Jr., B. C., Boering, K. A., Andrews, A. E., and Wofsy, S. C.: A high-precision fast-response airborne $\mathrm{CO} 2$ analyzer for in situ sampling from the surface to the middle stratosphere, J. Atmos. Oceanic Technol., 19, 1532-1543, doi:10.1175/15200426(2002)019<1532:AHPFRA>2.0.CO;2, 2002.

Daum, P. H., Kleinman, L. I., Springston, S. R., Nunnermacker, L. J., Lee, Y.-N., Weinstein-Lloyd, J., Zheng, J., and Berkowitz, C. M.: A comparative study of $\mathrm{O}_{3}$ formation in the Houston urban and industrial plumes during the 2000 Texas Air Quality Study, J. Geophys. Res., 108, 4715, doi:10.1029/2003JD003552, 2003.

de Gouw, J. A. and Warneke, C.: Measurements of volatile organic compounds in the earth's atmosphere using proton-transferreaction mass spectrometry, Mass Spectrom. Rev., 26, 223-257, doi:10.1002/mas.20119, 2007.

de Gouw, J. A., Middlebrook, A. M., Warneke, C., Goldan, P. D., Kuster, W. C., Roberts, J. M., Fehsenfeld, F. C., Worsnop, D. R., Canagaratna, M. R., Pszenny, A. A. P., Keene, W. C., Marchewka, M., Bertman, S. B., and Bates, T. S.: Budget of organic carbon in a polluted atmosphere: Results from the New England Air Quality Study in 2002, J. Geophys. Res., 110, D16305, doi:10.1029/2004JD005623, 2005.

de Gouw, J. A., Johansson, J., Mellqvist, J., Samuelsson, J., Offerle, B., and Rappenglück, B.: Airborne measurements of ethene from industrial sources using laser photo-acoustic spectroscopy, Environ. Sci. Technol, 43, 2437-2442, 2009.

Eom, I.-Y., Li, Q., Li, J., Dasgupta, P. K.: Robust hybrid flow analyzer for formaldehyde, Environ. Sci. Technol., 42, 1221-1226, 2008.

Friedfeld, S., Fraser, M., Ensor, K., Tribble, S., Rehle, D., Leleux, D., and Tittel, F.: Statistical analysis of primary and secondary atmospheric formaldehyde, Atmos. Environ., 36, 4767-4775, 2002.

Garcia, A. R., Volkamer, R., Molina, L. T., Molina, M. J., Samuelson, J., Mellqvist, J., Galle, B., Herndon, S. C., and Kolb, C. E.: Separation of emitted and photochemical formaldehyde in Mexico City using a statistical analysis and a new pair of gas-phase tracers, Atmos. Chem. Phys., 6, 4545-4557, doi:10.5194/acp-64545-2006, 2006.
Gilman, J. B., Kuster, W. C., Goldan, P. D., Herndon, S. C., Zahniser, M. S., Tucker, S. C., Brewer, W. A., Lerner, B. M., Williams, E. J., Harley, R. A., Fehsenfeld, F. C., Warneke, C., and de Gouw, J. A.: Measurements of volatile organic compounds during the 2006 TexAQS/GoMACCS campaign: Industrial influences, regional characteristics, and diurnal dependencies of the OH reactivity, J. Geophys. Res., 114, D00F06, doi:10.1029/2008JD011525, 2009.

Grosjean, D.: Formaldehyde and other carbonyls in Los Angeles ambient air, Environ. Sci. Technol,, 16, 254-262, 1982.

Holloway, J. S., Jakoubek, R. O., Parrish, D. D., Gerbig, C., VolzThomas, A., Schmitgen, S., Fried, A., Wert, B., Henry, B., and Drummond, J. R.: Airborne intercomparison of vacuum ultraviolet fluorescence and tunable diode laser absorption measurements of tropospheric carbon monoxide, J. Geophys. Res., 105, 24251-24261, doi:10.1029/2000JD900237, 2000.

Jiang, G. and Fast, J. D.: Modeling the effects of VOC and $\mathrm{NO}_{X}$ emission sources on ozone formation in Houston during the TexAQS 2000 field campaign, Atmos. Environ., 38, 5071-5085, doi:10.1016/j.atmosenv.2004.06.012, 2004.

Johansson, J., Mellqvist, J., Samuelsson, J., Offerle, B., and Rappenglück, B.: Investigation of VOC radical sources in the Houston Area by the Solar Occultation Flux (SOF) method and Mobile DOAS, Abstract A31B-0034 presented at 2010 Fall Meeting, AGU, San Francisco, Calif., 13-17 December 2010.

Kim, S.-W., McKeen, S. A., Frost, G. J., Lee, S.-H., Trainer, M., Richter, A., Angevine, W. M., Atlas, E., Bianco, L., Boersma, K. F., Brioude, J., Burrows, J. P., de Gouw, J., Fried, A., Gleason, J., Hilboll, A., Mellqvist, J., Peischl, J., Richter, D., Rivera, C., Ryerson, T., te Lintel Hekkert, S., Walega, J., Warneke, C., Weibring, P., and Williams, E.: Evaluations of $\mathrm{NO}_{\mathrm{x}}$ and highly reactive VOC emission inventories in Texas and their implications for ozone plume simulations during the Texas Air Quality Study 2006, Atmos. Chem. Phys., 11, 11361-11386, doi:10.5194/acp11-11361-2011, 2011.

Kleinman, L. I., Daum, P. H., Imre, D., Lee, Y.-N., Nunnermacker, L. J., Springston, S. R., Weinstein-Lloyd, J., and Rudolph, J.: Ozone production rate and hydrocarbon reactivity in 5 urban areas: A cause of high ozone concentration in Houston, Geophys. Res. Lett., 29, 1467, doi:10.1029/2001GL014569, 2002.

Kleinman, L. I., Daum, P. H., Imre, D., Lee, Y.-N., Nunnermacker, L. J., Springston, S. R., Weinstein-Lloyd, J., and Rudolph, J.: Correction to "Ozone production rate and hydrocarbon reactivity in 5 urban areas: A cause of high ozone concentration in Houston," Geophys. Res. Lett., 30, 1639, doi:10.1029/2003GL017485, 2003.

Lefer, B. and Rappenglück, B.: Preface: The TexAQS-II radical and aerosol measurement project (TRAMP), Atmos. Environ., 44, 3997-4004, 2010.

Li, S. M., Anlauf, K. G., Wiebe, H. A., Bottenheim, J. W., Shepson, P. B., and Biesenthal, T.: Emission ratios and photochemical production efficiencies of nitrogen oxides, ketones, and aldehydes in the Lower Fraser Valley during the summer Pacific 1993 oxidant study, Atmos. Environ., 31, 2037-2048, 1997.

Liu, Y., Shao, M., Kuster, W. C., Goldan, P. D., Li, X., Lu, S., and de Gouw, J. A.: Source identification of reactive hydrocarbons and oxygenated VOCs in the summertime in Beijing, Environ. Sci. Technol, 43, 75-81, doi:10.1021/es801716n, 2009. 
Martin, R. V., Parrish, D. D., Ryerson, T. B., Nicks Jr., D. K., Chance, K., Kurosu, T. P., Jacob, D. J., Sturges, E. D., Fried, A., and Wert, B. P.: Evaluation of GOME satellite measurements of tropospheric $\mathrm{NO}_{2}$ and $\mathrm{HCHO}$ using regional data from aircraft campaigns in the southeastern United States, J. Geophys. Res., 109, D24307, doi:10.1029/2004JD004869, 2004.

Mellqvist, J.: Application of infrared and UV-visible remote sensing techniques for studying the stratosphere and for estimating anthropogenic emissions, Ph.D. Thesis, Chalmers University of technology, Gothenburg, Sweden, 1999.

Mellqvist, J., Samuelsson, J., Johansson, J., Rivera, C., Lefer, B., Alvarez, S., and Jolly, J.: Measurements of industrial emissions of alkenes in Texas using the solar occultation flux method, J. Geophys. Res., 115, D00F17, doi:10.1029/2008JD011682, 2012a.

Mellqvist, J., Johansson, J., Samuelsson, J., Offerle, B., Rappenglück, B., Wilmot, C.-S., and Fuller, R.: Investigation of VOC radical sources in the Houston area by the Solar Occultation Flux (SOF) method, mobile DOAS (SOF-II) and mobile extractive FTIR, Final Report Project H-102, Texas Environmental Research Consortium: Houston, TX, 2010b.

Olaguer, E. P., Rappenglück, B., Lefer, B., Stutz, J., Dibb, J., Griffin, R., Brune, W. H., Shauck, M., Buhr, M., Jeffries, H., Vizuete, W., and Pinto, J. P.: Deciphering the role of radical precursors during the second Texas air quality study, J. Air Waste Manage. Assoc., 59, 1258-1277, doi:10.3155/10473289.59.11.1258, 2009.

Parrish, D. D.: Critical evaluation of US on-road vehicle emission inventories, Atmos. Environ., 40, 2288-2300, 2006.

Parrish, D. D., Allen, D. T., Bates, T. S., Estes, M., Fehsenfeld, F. C., Feingold, G., Ferrare, R., Hardesty, R. M., Meagher, J. F., Nielsen-Gammon, J. W., Pierce, R. B., Ryerson, T. B., Seinfeld, J. H., and Williams, E. J.: Overview of the Second Texas Air Quality Study (TexAQS II) and the Gulf of Mexico Atmospheric Composition and Climate Study (GoMACCS), J. Geophys. Res., 114, D00F13, doi:10.1029/2009JD011842, 2009.

Peischl, J., Ryerson, T. B., Holloway, J. S., Parrish, D. D., Trainer, M., Frost, G. J., Aikin, K. C., Brown, S. S. Dubé, W. P., Stark, H., and Fehsenfeld, F. C.: A top-down analysis of emissions from selected Texas power plants during TexAQS 2000 and 2006, J. Geophys. Res., 115, D16303, doi:10.1029/2009JD013527, 2010.

Possanzini, M., Di Palo, V., Petricca, M., Fratarcangeli, R., and Brocco, D.: Measurements of lower carbonyls in Rome ambient air, Atmos. Environ., 30, 3757-3764, 1996.

Rappenglück, B., Dasgupta, P. K., Leuchner, M., Li, Q., and Luke, W.: Formaldehyde and its relation to $\mathrm{CO}, \mathrm{PAN}$, and $\mathrm{SO}_{2}$ in the Houston-Galveston airshed, Atmos. Chem. Phys., 10, 24132424, doi:10.5194/acp-10-2413-2010, 2010.

Rivera, C., Mellqvist, J., Samuelsson, J., Lefer, B., Alvarez, S., and Patel, M. R.: Quantification of $\mathrm{NO}_{2}$ and $\mathrm{SO}_{2}$ emissions from the Houston Ship Channel and Texas City industrial areas during the 2006 Texas Air Quality Study, J. Geophys. Res., 115, D08301, doi:10.1029/2009JD012675, 2010.

Ryerson, T. B., Buhr, M. P., Frost, G. J., Goldan, P. D., Holloway, J. S., Hübler, G., Jobson, B. T., Kuster, W. C., McKeen, S. A., Parrish, D. D., Roberts, J. M., Sueper, D. T., Trainer, M., Williams, J., and Fehsenfeld, F. C.: Emissions lifetimes and ozone formation in power plant plumes, J. Geophys. Res., 103, 22569-22583, doi:10.1029/98JD01620, 1998.
Ryerson, T. B., Huey, L. G., Knapp, K., Neuman, J. A., Parrish, D. D., Sueper, D. T., and Fehsenfeld, F. C.: Design and initial characterization of an inlet for gas-phase $\mathrm{NO}_{\mathrm{y}}$ measurements from aircraft, J. Geophys. Res., 104, 5483-5492, doi:10.1029/1998JD100087, 1999.

Ryerson, T. B., Williams, E. J., and Fehsenfeld, F. C.: An efficient photolysis system for fast-response $\mathrm{NO}_{2}$ measurements, J. Geophys. Res., 105, 26447-26461, doi:10.1029/2000JD900389, 2000.

Ryerson, T. B., Trainer, M., Angevine, W. M., Brock, C. A., Dissly, R. W., Fehsenfeld, F. C., Frost, G. J., Goldan, P. D., Holloway, J. S., Hübler, G., Jakoubek, R. O., Kuster, W. C., Neuman, J. A., Nicks Jr., D. K., Parrish, D. D., Roberts, J. M., Sueper, D. T., Atlas, E. L., Donnelly, S. G., Flocke, F., Fried, A., Potter, W. T., Schauffler, S., Stroud, V., Weinheimer, A. J., Wert, B. P., Wiedinmyer, C., Alvarez, R. J., Banta, R. M., Darby, L. S., and Senff, C. J.: Effect of petrochemical industrial emissions of reactive alkenes and $\mathrm{NO}_{\mathrm{x}}$ on tropospheric ozone formation in Houston, Texas; J. Geophys. Res., 108, 4249, doi:10.1029/2002JD003070, 2003.

Schauffler, S. M., Atlas, E. L., Blake, D. R., Flocke, F., Lueb, R. A., Lee-Taylor, J. M., Stroud, V., and Travnicek, W.: Distributions of brominated organic compounds in the troposphere and lower stratosphere, J. Geophys. Res., 104, 21513-21535, doi:10.1029/1999JD900197, 1999.

Seinfeld, J. H. and Pandis, S. N.: Atmospheric Chemistry and Physics: From Air Pollution to Climate Change, John Willey \& Sons, Inc., New York, 1998.

Stutz, J., Pikelnaya, O., Mount, G., Spinei, E., Herndon, S., Wood, E., Oluwole, O., Vizuette, W., and Causo, E.: Quantification of Hydrocarbon, $\mathrm{NO}_{\mathrm{x}}$, and $\mathrm{SO}_{2}$ emissions from Petrochemical $\mathrm{Fa}$ cilities in Houston: Interpretation of the 2009 FLAIR dataset, Final Report for Air Quality Research Program, project 10-045, Texas Environmental Research Consortium: Houston, TX, 2011.

Warneke, C., McKeen, S. A., de Gouw, J. A., Goldan, P. D., Kuster, W. C., Holloway, J. S., Williams, E. J., Lerner, B. M., Parrish, D. D., Trainer, M., Fehsenfeld, F. C., Kato, S., Atlas, E. L., Baker, A., and Blake, D. R.: Determination of urban volatile organic compound emission ratios and comparison with an emissions database, J. Geophys. Res., 112, D10S47, doi:10.1029/2006JD007930, 2007.

Washenfelder, R. A., Trainer, M., Frost, G. J., Ryerson, T. B., Atlas, E. L., de Gouw, J. A., Flocke, F. M., Fried, A., Holloway, J. S., Parrish, D. D., Peischl, J., Richter, D., Schauffler, S. M., Walega, J. G., Warneke, C., Weibring, P., and Zheng, W.: Characterization of $\mathrm{NO}_{x}, \mathrm{SO}_{2}$, ethene, and propene from industrial emission sources in Houston, Texas, J. Geophys. Res., 115, D16311, doi:10.1029/2009JD013645, 2010.

Weibring, P., Richter, D., Walega, J. G., and Fried, A.:First demonstration of a high performance difference frequency spectrometer on airborne platforms, Optics Express, 15, 13476-13495, 2007.

Wert, B. P., Trainer, M., Fried, A., Ryerson, T. B., Henry, B., Potter, W., Angevine, W. M., Atlas, E., Donnelly, S. G., Fehsenfeld, F. C., Frost, G. J., Goldan, P. D., Hansel, A., Holloway, J. S., Hubler, G., Kuster, W. C., Nicks Jr., D. K., Neuman, J. A., Parrish, D. D., Schauffler, S., Stutz, J., Sueper, D. T., Wiedinmyer, C., and Wisthaler, A.: Signatures of terminal alkene oxidation in airborne formaldehyde measurements during TexAQS 2000; J. Geophys. Res., 108, 4104, doi:10.1029/2002JD002502, 2003. 